\title{
Archeolog jako badacz i popularyzator: doświadczenia z Targu Siennego
}

Marta Wołyńska | Wydział Historyczny, Uniwersytet Gdański

Słowa kluczowe:

archeologia,

edukacja,

popularyzacja,

dziedzictwo

społeczny kontekst archeologii

\section{Streszczenie}

Przedmiotem artykułu jest omówienie podwójnej roli archeologa: badacza i popularyzatora. We wstępie wskazane są definicje tej dyscypliny i długa historia upowszechniania wyników jej badań. Kolejna część artykułu omawia prezentowane w literaturze metody popularyzacji i edukacji archeologicznej. Punkt wyjścia stanowi kwestia społecznego postrzegania archeologii jako dziedziny akademickiej lub rozrywki oraz pytanie o zapotrzebowanie na przekazywane przez nią treści. Sposobem na podjęcie dialogu pomiędzy archeologami a społeczeństwem mogą być badania ankietowe. Umożliwiają one tworzenie odpowiadającego oczekiwaniom odbiorców programu poszerzania wiedzy o dziedzictwie. Bezpośredni kontakt z przedstawicielami dyscypliny stanowi również okazję do kształtowania pozytywnego wizerunku archeologii jako nauki społecznie użytecznej. W tekście wskazane są wyzwania, które stoją przed współczesną archeologią i wpływają na postawę badacza. Poruszany jest problem komercjalizacji tej nauki i przekładanie się tego zjawiska na charakter oraz zakres badań i możliwości ich prezentacji. Główna część wypowiedzi przedstawia działania popularyzacyjne prowadzone przez pracowników firmy prywatnej - Pracowni Badań Archeologicznych Dantiscum. Projekt powstał w związku z wykopaliskami realizowanymi na obszarze zachodniego przedmieścia Gdańska, na stanowisku na Targu Siennym. Badania naukowe i upowszechnianie archeologii w formie wystawy i prelekcji były prowadzone we współpracy z instytucjami, takimi jak muzeum czy uniwersytet. Prezentowane działania stanowią przejaw społecznego modelu uprawiania tej dyscypliny, nastawionego na partycypację odbiorcy. Podstawową, podkreślaną w artykule kwestią jest duży społeczny potencjał archeologii, którego odpowiednie wykorzystanie może diametralnie zmienić perspektywy jej rozwoju.

\section{Archaeologist - researcher and populariser, experiences from Targ Sienny Summary}

Keywords: archaeology, education popularisation, heritage, of archaeology
The aim of the article is to present a double role of an archaeologist - a role of a researcher and a popularizer. In the introduction there are the definitions of archaeology and a long story of popularizing the results of its research. The first chapter describes the methods of popularizing and archaeological 
education which are presented in the literature. The main point is the matter of the social perception of archaeology as an academic discipline or entertainment and the matter to what extend society really needs it. One way to start a dialogue between the audience and scientists might be a survey. This method enables archaeologists to introduce an appropriate programme which may broaden people's knowledge about the heritage. A direct contact with an archaeologist makes an occasion to create a positive image of archaeology as a socially useful discipline. The article presents the challenges faced by contemporary archaeology that have an influence on researchers. One of the problems presented in the article is commercialization of that discipline and to what extend it might influence the research and its presentation. The main part describes the activities taken by the private company Pracownia Badań Archeologicznych Dantiscum to popularize archaeology. The project was introduced in connection to excavations in the western suburbs of Gdańsk at the Targ Sienny site. Archaeological research and popularizing archaeology in the form of an exhibition and the lectures were conducted in cooperation with the institutions such as museums and the University. The activities presented here are the example of a new approach that takes participation of audience into consideration. Basic and the most emphasized issue is the social potential of archaeology, which used in the appropriate way might change the prospects of its development.

\section{Wstęp}

Jak należy rozumieć termin „archeologia”? Czym właściwie zajmuje się ta dziedzina? Witold Hensel w swojej pracy pt. Zakres i zadania archeologii określił ją jako „naukę historyczną, której przedmiotem jest naukowa realizacja badań wykopaliskowych lub innych prac odkrywczych oraz analiza uzyskanych w ich toku źródeł, a także inwentaryzacja oraz studia nad przetrwałymi do dziś dawnymi elementami krajobrazu historycznego" (Hensel 1973: 131). Do zadań tej dyscypliny zaliczył więc pozyskanie, opracowanie, zabezpieczenie i udostępnienie zabytków społeczeństwu. Należy podkreślić tę ostatnią z funkcji, ponieważ zdaniem tego autora wydobyte „źródła mają ogromne znaczenie w rozwoju ideologii, świadomości historycznej społeczeństwa" (Hensel 1973: 133).

Rozważania na temat definicji i funkcji archeologii znalazły się również w publikacji Michała Pawlety pt. Przeszłość we współczesności. Studium metodologiczne archeologicznie kreowanej przeszłości w przestrzeni społecznej. Według badacza: „Archeologia, tworząca wiedzę na temat najdawniejszych dziejów społeczności ludzkich, z założenia jest zorientowana społecznie" (Pawleta 2016a: 81). Do jej zadań zaliczył funkcję naukową (poznawczą), polegającą na „powiększaniu zasobu wiedzy na temat przeszłości”, konserwatorską („ochrona dziedzictwa archeologicznego”), edukacyjną (popularyzatorską), w której zakres wchodzi „przekazywanie społeczeństwu wiedzy na temat przeszłości” oraz dyskursywną, rozumianą jako „udział archeologii w dyskursie o teraźniejszości, włączając w to funkcję polityczną oraz światopoglądową" (Pawleta 2016a: 82). W tych rozważaniach należy jednak zwrócić uwagę na fakt, że wraz z przemianami ustrojowymi w 1989 r. i pojawieniem się gospodarki wolnorynkowej wyodrębnił się sektor prywatnych firm archeologicznych oraz konsorcjów (Pawleta 2016a: 103), 
a archeologia zaczęła egzystować w ramach działalności gospodarczej (Kobyliński 2010: 13, 18). Doprowadziło to do sytuacji „traktowania jej jako usługi bądź rzemiosła" (Pawleta 2016a: 117) i komercjalizacji tej dziedziny. W rezultacie doszło do podziału „polskiego środowiska archeologicznego na archeologię akademicką oraz komercyjną" (Pawleta 2016a: 103).

Dla stworzenia pełnego obrazu profesji istotne jest również spojrzenie z perspektywy społeczeństwa. W przykładowych badaniach z wykorzystaniem ankiet przeprowadzonych w Polsce (Kajda, Pawleta, Marciniak 2017: 71-84) dla 3/5 pytanych respondentów podstawą do zdefiniowania tej dziedziny były jej metody badawcze, w związku z tym w ich opinii ,archeologia to wykopywanie/wykopaliska różnych obiektów, artefaktów, pozostałości czy szczątków ludzkich" (Kajda, Pawleta, Marciniak 2017: 74). Natomiast ponad połowa uczestników badania postrzegała archeologię jako "ściśle związaną ze zdobywaniem wiedzy na temat przeszłości" (Kajda, Pawleta, Marciniak 2017: 75)'.

Na weryfikację powyższych definicji pozwoliło autorce osobiste zetknięcie się z przedstawicielami społeczeństwa. Takie sytuacje były częste w trakcie prac terenowych, ponieważ „w przypadku archeologii to niejednokrotnie naukowcy wkraczają w przestrzenie na co dzień uważane za zwykłe, czasem nieistotne i rozpoczynają swoje działania w miejscach, w których (lub obok których) toczy się życie codzienne" (Kajda, Pawleta, Marciniak 2017: 80). Te spotkania potwierdziły wyniki przytoczonych badań statystycznych (Kajda, Pawleta, Marciniak 2017: 74). Spowodowały również refleksje nad społeczną rolą archeologii we współczesnym świecie oraz metodami zwiększenia jej wpływu na teraźniejszość. Przyjętym rozwiązaniem było rozwijanie działań popularyzatorskich polegających na prezentacji wyników gdańskich wykopalisk.

Upowszechnianie odkryć archeologicznych ma bardzo długą tradycję. Zostało zainicjowane przez towarzystwa miłośników starożytności i stowarzyszenia naukowe, które w okresie bezpaństwowości rozwijały kolekcjonerstwo, wystawiennictwo oraz działalność wydawniczą. Stopniowo rolę tę przejęły powstające muzea archeologiczne, placówki uniwersyteckie oraz czasopisma, takie jak "Przegląd Archeologiczny” czy "Z Otchłani Wieków". Cele były realizowane np. przez publikacje popularnonaukowe, wykłady, organizowane w trakcie badań wykopaliskowych odczyty i pogadanki. Działalność popularyzatorską prowadzili tacy wybitni badacze, jak Erazm Majewski czy Józef Kostrzewski (asumpt stanowiło np. odkrycie Biskupina) (Radziszewska 2009: 99, 100; Pawleta 2016a: 91, 92)². Po Il wojnie światowej popularyzacja archeologii prowadzona była przez zawodowych archeologów $w$ ramach instytucji

${ }^{1}$ Te proporcje były odwrotne $w$ badaniach ankietowych przeprowadzonych w innych krajach europejskich (Kajda i in. 2017: 10, 12).

${ }_{2}$ Józef Kostrzewski zajmował się również usuwaniem zniekształceń rzeczywistości pradziejowej dokonanych przez kulturę popularną. Analizował obraz pradziejów w literaturze pięknej/popularnej, wskazując jednak zawsze pozytywne (popularyzatorskie) aspekty utworu (Kobiałka 2013: 120-123); Celem czasopisma "Z Otchłani Wieków" "jest m.in. zaznajomienie szerszego ogółu inteligencji z badaniami prehistorji. Apel do nauczycielstwa, duchowieństwa i ziemiaństwa, mających najwięcej styczności z ludem, aby poparli dążenie do spopularyzowania prehistorji i ratowania zabytków przeddziejowych od zagłady" (Od redakcji 1926: 1-3, cyt. za: Malinowski 2016: 371). 
państwowych: muzeów archeologicznych oraz rezerwatów (Pawleta 2016a: 97, 100). Na stałą aktualność tych problemów wskazują ostatnie publikacje (Chowaniec 2010; Kajda, Pawleta, Marciniak 2017: 71-84).

W przypadku autorki, dla prowadzenia badań realizowanych w ramach studiów doktoranckich oraz popularyzacji ich wyników, niezmiernie istotne było podjęcie pracy w firmie archeologicznej. Dzięki takiemu połączeniu obowiązki zawodowe mogły stać się zbieżne z obszarem zainteresowań badawczych. Niebagatelna była też kwestia, iż pracodawca - firma Dantiscum - prowadziła wykopaliska na wyjątkowo interesującym stanowisku na Targu Siennym, na terenie zachodniego przedmieścia Gdańska ${ }^{3}$ (ryc. 1). Prace dostarczyły ponad siedmiu tysięcy zabytków o charakterze wystawienniczym (ryc. 2) i umożliwiły odsłonięcie m.in. reliktów zabudowy mieszkalnej i przemysłowej (ryc. 3). W opinii Anny Zalewskiej $(2012,49)$ „Archeologia nieustannie wpisuje się w miasto, zakotwicza się w nim i zderza z przestrzenią miejską, wywierając większy lub mniejszy wpływ na specyfikę przemian miast" ${ }^{4}$. Odnosząc się do kwestii inwestycji, a więc ingerencji w tkankę miasta, można również nawiązać do wypowiedzi Artura Trapszyca $(2016: 105,107)$ i jego refleksji na temat istoty dialogu między materią a duchem miasta. Autor podkreśla, jak istotna jest dla kultury, wręcz podstawowa, relacja pomiędzy jej aspektem materialnym a niematerialnym. W tym przypadku rozpatrywana w kontekście dziedzictwa ośrodków miejskich. Niestety, mimo tradycji w ochronie niematerialnego aspektu kultury problem $\mathrm{np}$. ochrony krajobrazów nadal pozostaje nierozwiązany. Jego stała degradacja stanowi zaś skutek niepożądanych lub źle zaplanowanych inwestycji. Taka sytuacja miała również miejsce w przypadku Targu Siennego. Zabudowa obszaru zachodniego przedmieścia Głównego Miasta zmieniła całkowicie dotychczasowy wygląd Gdańska ${ }^{5}$. Dlatego jedynie prezentacja odkrytych w tym miejscu zabytków ruchomych i nieruchomych może przypomnieć o pierwotnej funkcji przestrzeni przedmieścia ${ }^{6}$. Kwestia pamięci jest $w$ tym przypadku szczególnie skomplikowana z uwagi na fakt, że nie mamy na terenie Gdańska do czynienia z ciągłością etniczną.

\footnotetext{
3 Prace realizowano w związku z budową Forum Gdańsk, w okresie od sierpnia 2014 do 5 stycznia 2017 r.

4 Anna Zalewska (2012: 49-65) opisuje zagrożenia i szanse, jakie stoją przed archeologią miejską.

${ }^{5}$ Większość respondentów z krajów europejskich utrzymywała, że budowa powinna być przełożona na później, gdy zostaną odkryte relikty archeologiczne. To sugeruje, że dla większości społeczeństwa ochrona i ratowanie dziedzictwa jest ważniejsze niż tempo rozwoju (Kajda i in. 2017: 12).

${ }^{6}$ Ankiety ujawniły, że olbrzymia część (90\%) społeczeństwa postrzega dziedzictwo archeologiczne jako korzystne dla miast i jako coś co powinno być wspierane i rozwijane (Kajda i in. 2017: 17).
} 


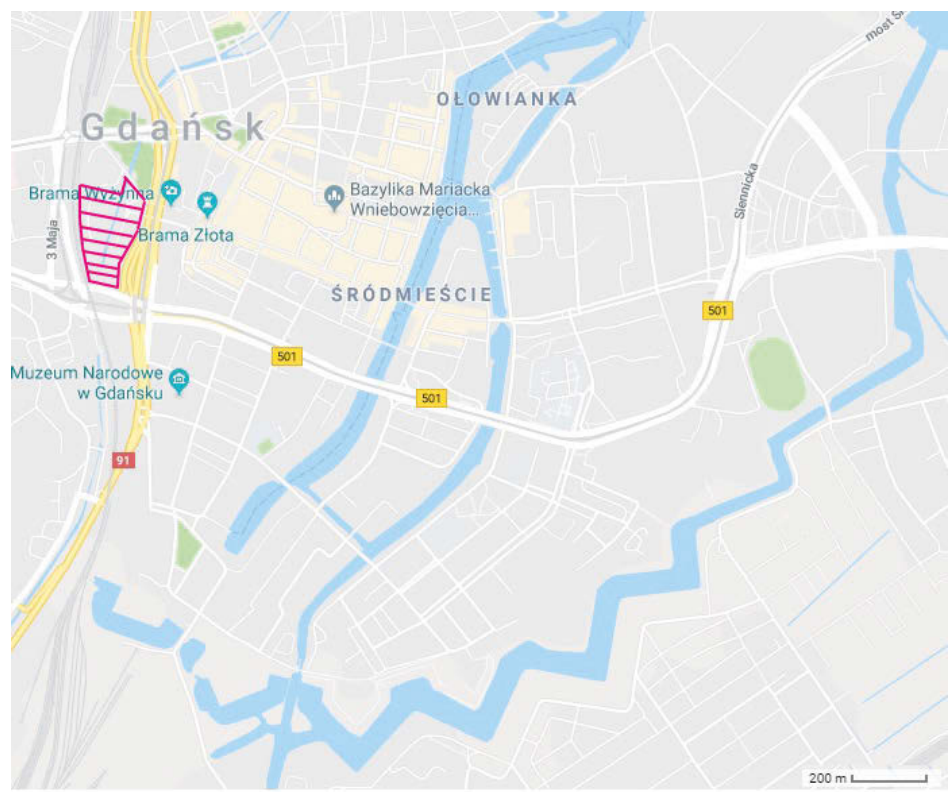

1. Lokalizacja stanowiska na Targu Siennym

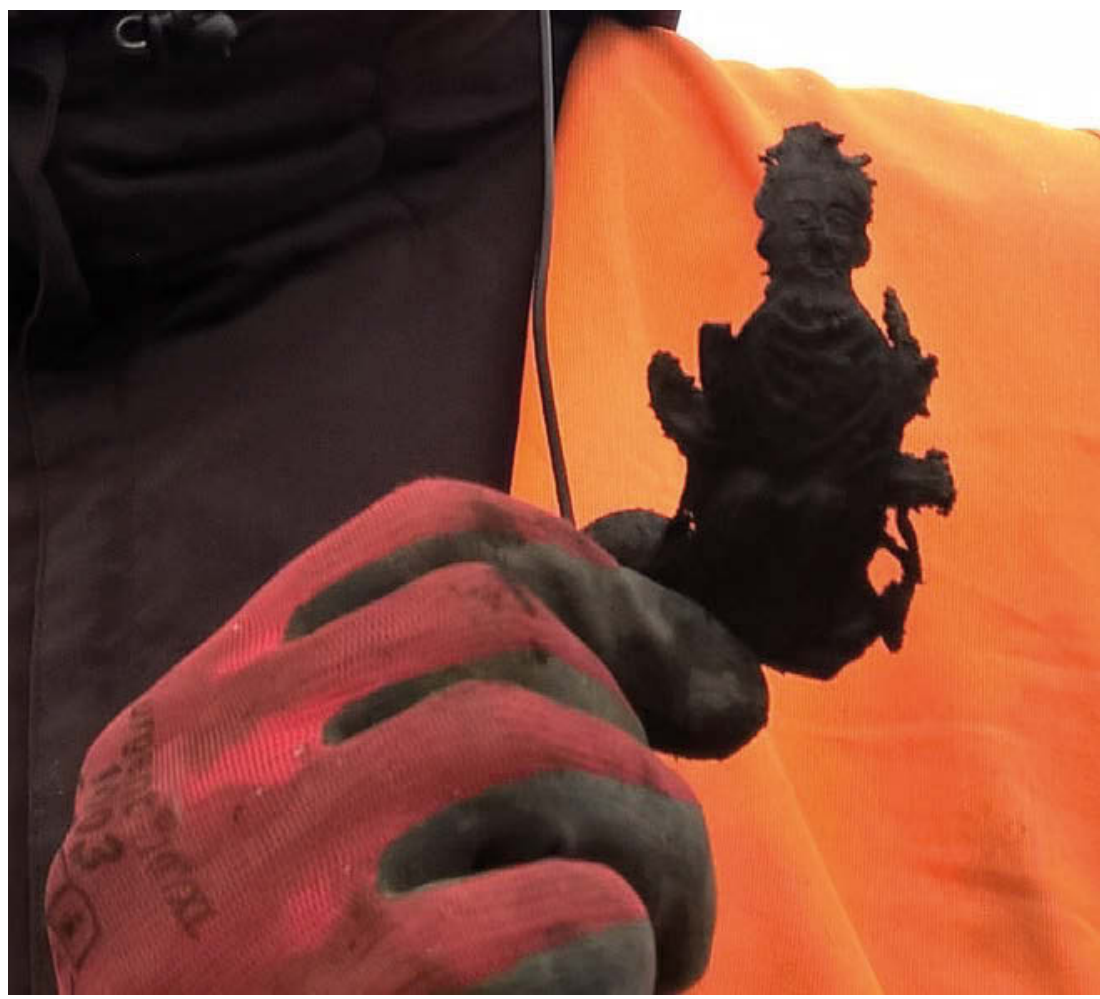

2. Plakietka pozyskana podczas badań na Targu Siennym (fot. Marta Wołyńska) 


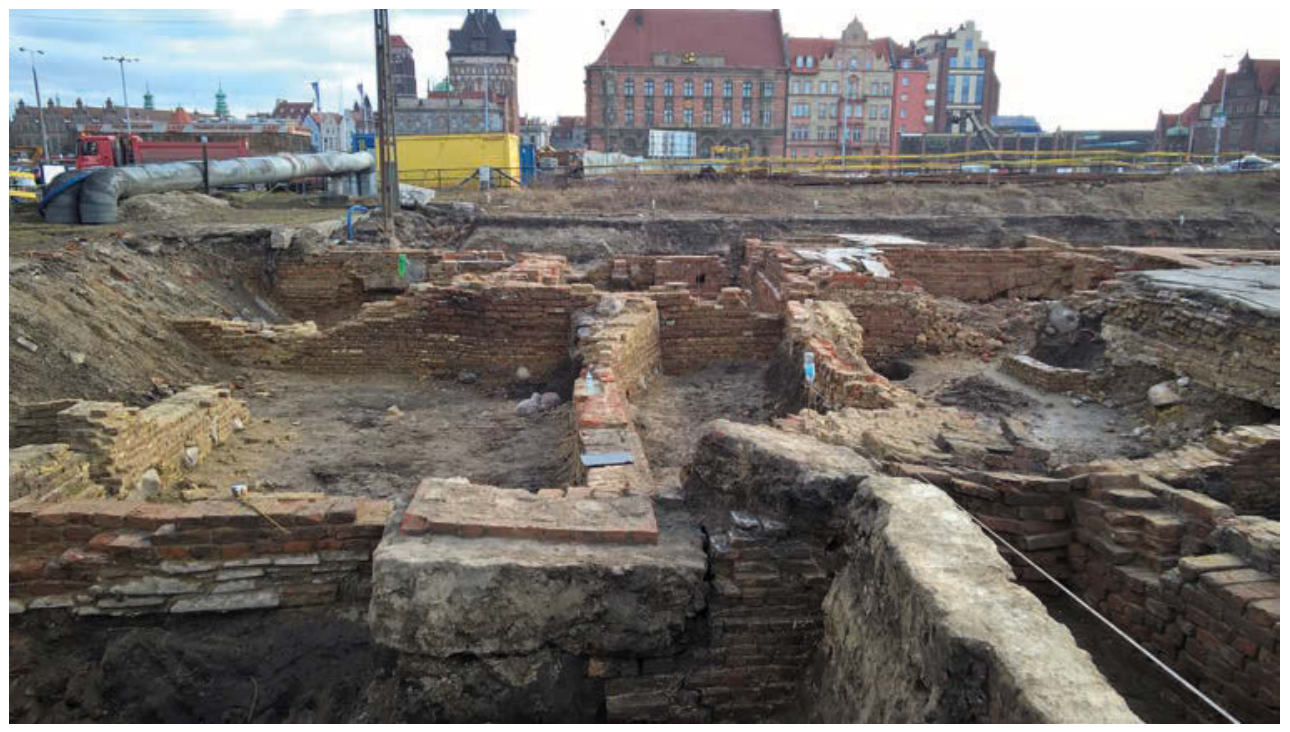

\section{Relikty zabudowy na Targu Siennym na tle Głównego Miasta (fot. Marta Wołyńska)}

Część z pozyskanych w trakcie badań środków została przeznaczana przez pracodawcę na objazdy naukowe. Wyjazdy do Brugii (ryc. 4-6) czy Amsterdamu (ryc. 7) dawały możliwość wykonania kwerendy, poprzedzającej opracowanie pozyskanych w trakcie badań zabytków. Wizyty w miejscowych muzeach pozwalały na zapoznanie się z oryginalnymi dziełami sztuki, stanowiącymi znakomitą ikonografię dla gdańskich zbiorów (ryc. 8 a, b) ${ }^{7}$. Wyjazdy umożliwiły również ogląd zabytków archeologicznych (ryc. 9) i doświadczenie kultury miast należących kiedyś, tak jak Gdańsk, do Hanzy.

Celem artykułu jest zaprezentowanie dualistycznej roli archeologa, polegającej na łączeniu zadań naukowych z popularyzacją swojej dziedziny. W następnej części pracy zostanie prześledzone kształtowanie się poglądów na tę kwestię w literaturze przedmiotu. Główną część tekstu stanowi studium przypadku oparte na własnych doświadczeniach autorki, omawiające prace archeologiczne na Targu Siennym w Gdańsku oraz formy ich prezentacji. Można postawić tezę, że dwa oblicza pracy archeologa, naukowe i popularyzatorskie, tworzą nierozerwalną całość. Upowszechnianie wyników badań wykopaliskowych stanowi integralną część uprawiania archeologii, dziedziny, która nie może funkcjonować bez jej społecznego, popularyzatorskiego wymiaru.

\footnotetext{
7 Doskonały przykład może stanowić eksponowany w Rijksmuseum w Amsterdamie obraz Pietera Aertsena Taniec z jajkiem (1552). Dzieło prezentuje codzienne zastosowanie solniczki, przedmiotu, którego materialny odpowiednik został pozyskany podczas badań na Targu Siennym (obraz dostępny na stronie Rijksmuseum).
} 


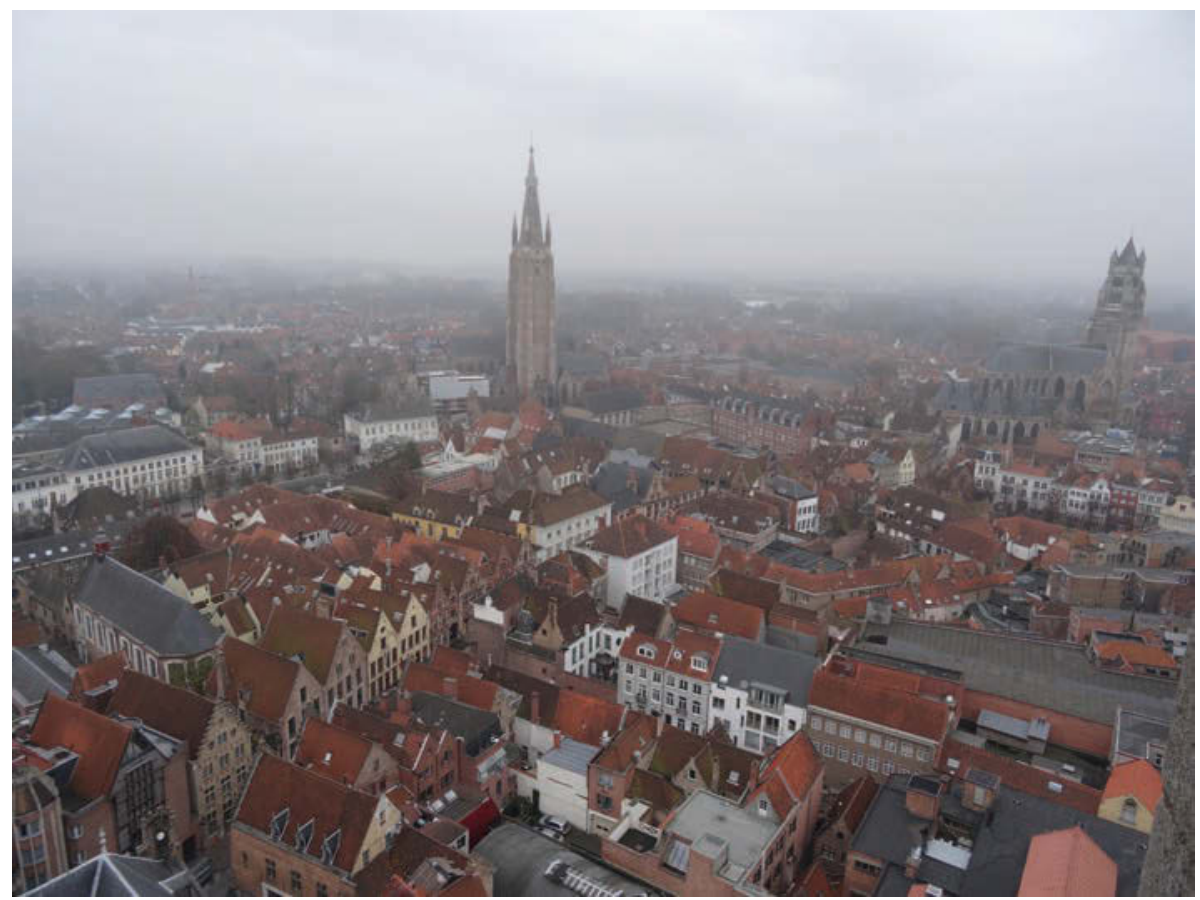

4. Panorama Brugii (fot. Marta Wołyńska)

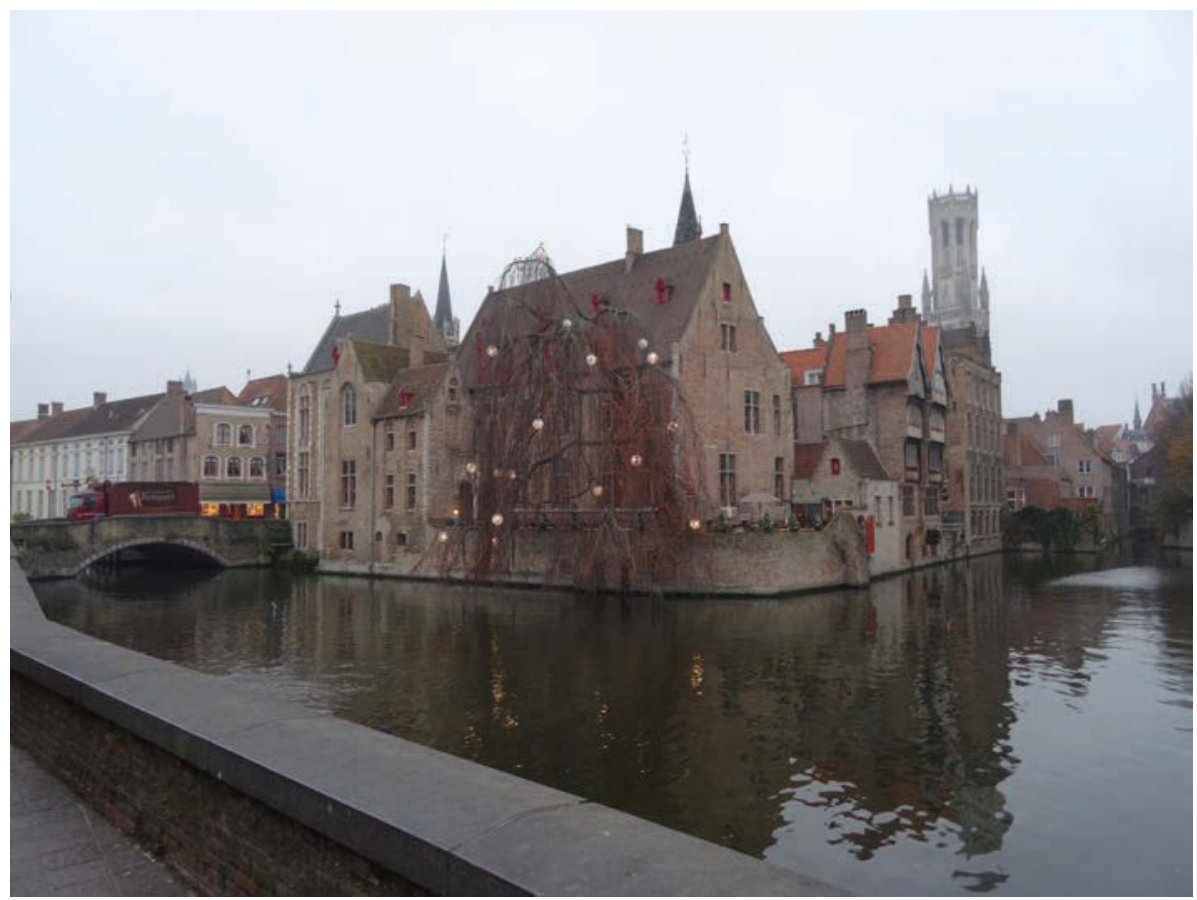

5. Kanały Brugii (fot. Marta Wołyńska) 


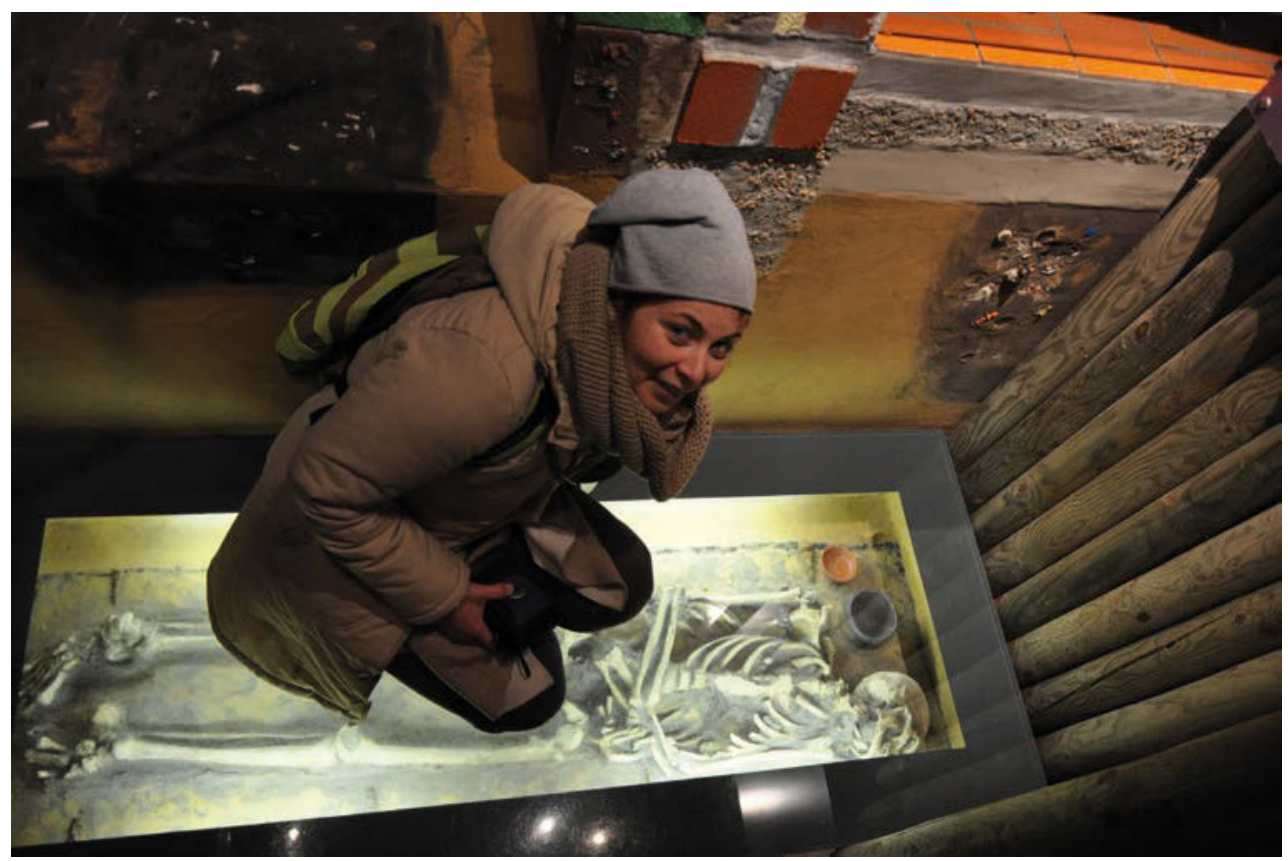

6. Muzeum Archeologiczne w Brugii (fot. Robert Krzywdziński)

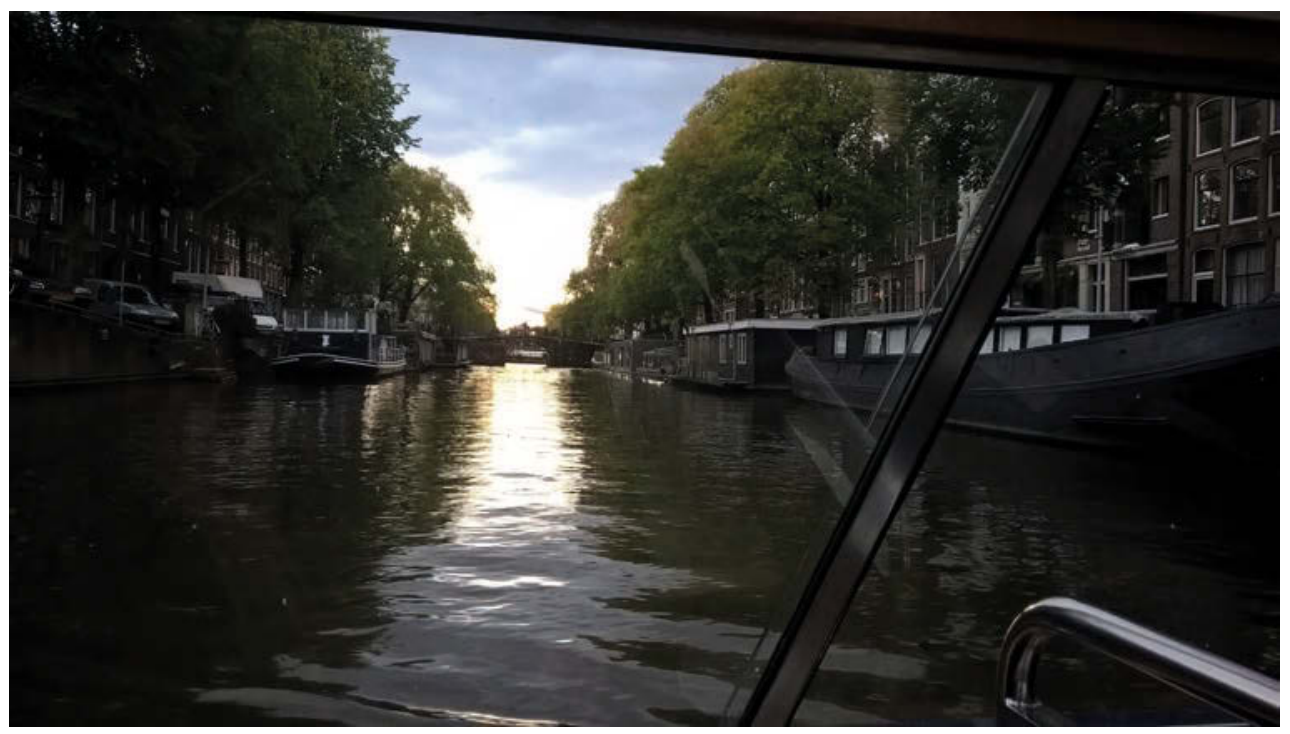

7. Kanały Amsterdamu (fot. Marta Wołyńska) 

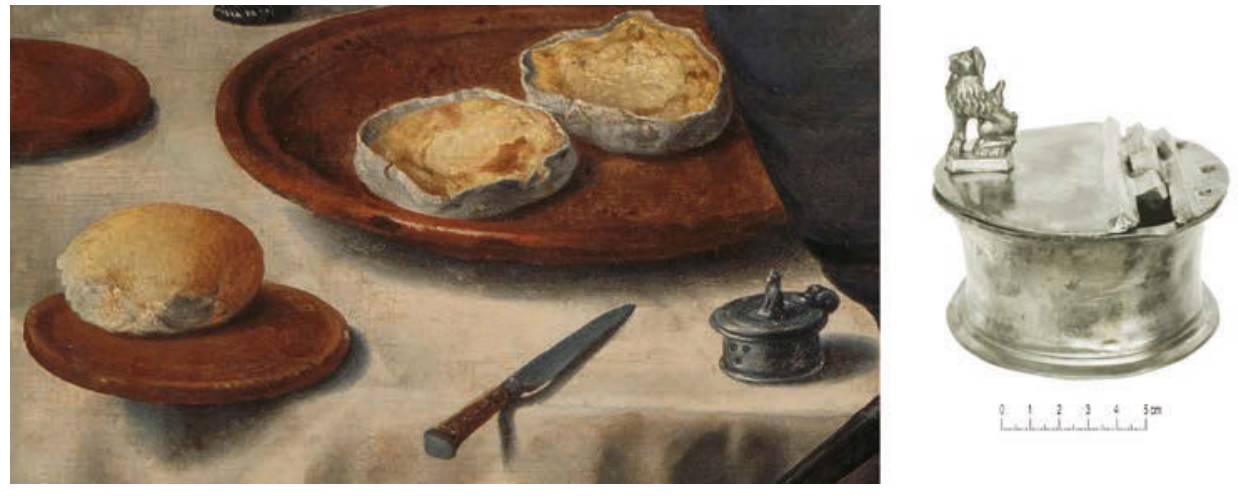

8. a - Taniec z jajkiem, Pieter Aertsen, 1552; Rijksmuseum, Amsterdam. b - Solniczka ze stanowiska na Targu Siennym w Gdańsku (Krzywdziński, 2016: 107, pozycja 182)

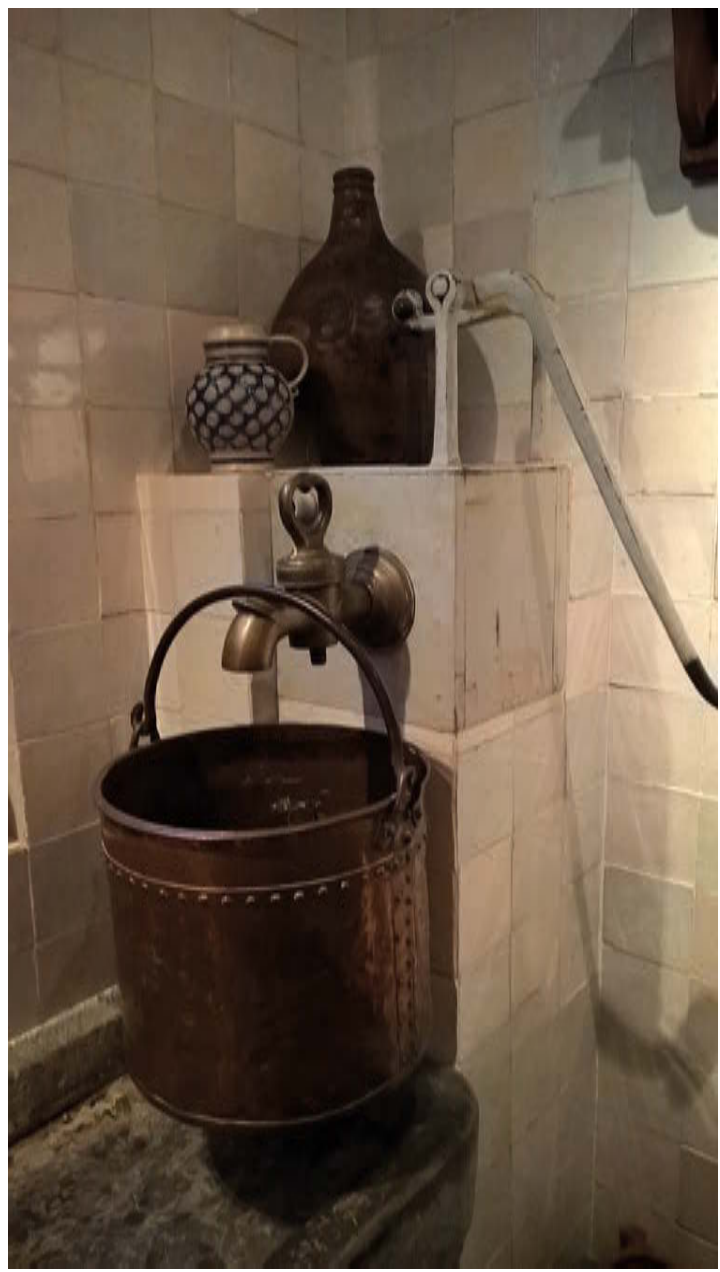

9. Kuchnia w Muzeum Rembrandta w Amsterdamie (fot. Marta Wołyńska) 


\section{Archeolog - badacz i popularyzator}

Dużą przeszkodę w realizacji celów archeologii - co postaram się wskazać w tej części artykułu - stanowią niejasne relacje (wzajemne oczekiwania) pomiędzy społeczeństwem a archeologami (Kajda 2013: 210) i publiczny odbiór tej dziedziny nauki. Pierwsze zadanie, jakie więc staje przed archeologiem, to prezentacja własnego warsztatu badawczego oraz obszaru pracy. W ujęciu Zygmunta Baumana (2006: 95-101, za Kobiałka 2011: 140, 141) praca archeologa postrzegana jest często jako rodzaj przygody ${ }^{8}$. Natomiast z badań prowadzonych przez Kornelię Kajdę i Mikołaja Kostyrko (2016: 20) wynika, że aktywność zawodowa czasami jest łączona „z przygodami, poszukiwaniem skarbów, pracą w egzotycznych krajach i tajemniczych miejscach. Zasadniczo, nie jest to jednak najbardziej popularny wizerunek archeologów, który istnieje w społecznej wyobraźni". Jak już wspomniano we wstępie, dominuje opinia, że archeolog to badacz przeszłości, który poznaje ją podczas prac wykopaliskowych. W tym przypadku spotykamy się z neutralną lub pozytywną reakcją społeczną ${ }^{9}$. Z odmiennym nastawieniem mamy do czynienia w chwili, gdy zwykły obywatel z uwagi na wymogi ustawowe musi skorzystać $z$ usług archeologa. W takich wypadkach objawia się nie tyle nastawienie negatywne, co lęk dotyczący charakteru, zakresu, a w głównej mierze czasu trwania i, co za tym idzie, kosztów prac archeologicznych. Na tego typu podejście wpływa brak elementarnej wiedzy o tej działalności lub mglisty obraz jej naukowego charakteru ${ }^{10}$. Jest to nadal widoczne, mimo prezentowanej $w$ literaturze (Kajda 2013: 210) i potwierdzonej przez ostatnie badania (Kajda i in. 2017: 13) opinii, że archeologia postrzegana jest głównie jako dziedzina akademicka. Od kilkunastu do 25\% Europejczyków wiąże ją jednak z działalnością kulturalną, co może stanowić efekt festynów archeologicznych. Natomiast średnio $26 \%$ respondentów określa archeologię jako profesję. Oznacza to, że w mniejszym stopniu utożsamiana jest z podmiotami gospodarczymi świadczącymi usługi w formie badań np. dla rynku deweloperskiego (Kajda i in. 2017: 13). Podobne spostrzeżenia można było poczynić na podstawie rozmów z przedstawicielami społeczeństwa. Wzmianka o wykopaliskach wywoływała skojarzenia z muzeum archeologicznym. Tymczasem większość z badań (przykładowo Gdańsk) ma charakter komercyjny (Wołyńska 2018: 71, 72, 157). Mimo rangi odkryć postrzeganie takich działań zmierza do poziomu „prac ziemnych czy robót drogowych" prowadzonych na masową skalę (Pawleta 2016a: 118).

Dominująca obecnie postawa konsumpcyjna dotyka także archeologię (Kobiałka 2011: 138). Dla Michała Pawlety (2011: 85) kluczowe jest pytanie, czy człowiekowi

${ }^{8}$ O fascynacji archeologią opowiada Dawid Kobiałka (2011: 135, 137, 140-142). Autor nawiązuje do wszechobecnego utożsamiania tej dziedziny z fikcyjnymi postaciami, takimi jak Indiana Jones czy Lara Croft. Zdaniem badacza to właśnie bohaterowie filmów i gier komputerowych kształtowali jej obraz.

9 Badania europejskie wykazały, że większość respondentów postrzega archeologię i dziedzictwo w sposób pozytywny (Kajda i in. 2017: 6).

${ }^{10}$ W literaturze pojawiają się jednak również odmienne opinie, sugerujące że stan świadomości archeologicznej, a więc i potrzeby ochrony dziedzictwa, jest w społeczeństwie zadowalający (Gołębnik, Grubka 2005; 2006: 62). 
współczesnemu potrzebna jest przeszłość, a jeśli tak, to w jakiej roli? Badacz sugeruje wybiórcze podejście odbiorców z nastawieniem na atrakcyjność i widowiskowość (Pawleta 2011: 86, 87). Autor wyraża obawę o komercjalizację dziedzictwa, np. w przypadku mających wymiar edukacyjny i popularyzacyjny festynów i jarmarków archeologicznych (Pawleta 2011: 92-93). Również Anna Zalewska (2011: 122) twierdzi, że: „Wolnorynkowość i utowarowienie wiedzy archeologicznej wywierają poważny wpływ nie tylko na kondycję dziedziny, ale i na jej obraz w oczach przeciętnego Polaka". Europejskie badania ankietowe wykazały jednak duże zainteresowanie dziedzictwem, biernym i czynnym udziałem w projektach archeologicznych oraz zawodem archeologa. Dowiodły, że archeologia jest postrzegana w Europie jako społeczna wartość, ale stanowi dyscyplinę niewystarczająco upowszechnianą (Kajda i in. 2017: 12, $18,19)$. Ta próżnia informacyjna, za którą odpowiadają badacze, sprawia, że odbiorcy zwracają się w stronę istniejącej, choćby festynowej wizji przeszłości. Archeolog jako badacz i popularyzator ma natomiast możliwość wielowymiarowej ochrony dziedzictwa postrzeganego przez Gregory'ego Ashwortha jako „proces użytkowania przeszłości, wykorzystywania »nośników historycznych « w celu zaspokajania różnorodnych współczesnych potrzeb społecznych, kulturowych, politycznych etc." (2015: 21-22, cyt. za: Gajda 2016: 285) Według Ashwortha przeszłość przejawia się w teraźniejszości m.in. przez artefakty, stąd też tak duża rola dla archeologii.

Niebagatelna jest kwestia dużego zainteresowania tą nauką (Kajda, Kostyrko 2016: 20). Stanowi ono olbrzymi potencjał, którego nie można zmarnować. Kobiałka (2011:136) mówi wręcz o „archeomanii”, czyli „społecznej fascynacji tą dziedziną wiedzy”. O skali zjawiska może świadczyć fakt, że „kwestie popularyzacji, sposoby dialogu pomiędzy archeologią a ludźmi nią zainteresowanymi" stały się obszarem badawczym dla tzw. archeologii publicznej". Pojęcie to zostało wprowadzone do nauki na początku lat 70. XX wieku w Stanach Zjednoczonych jako określenie na zarządzanie dziedzictwem kulturowym (McGimsey 1972, za Deskur 2009: 283). Od lat 90. ubiegłego wieku archeologia publiczna zajmuje się kontaktami archeologów ze społeczeństwem. W USA służy do formalnego rozwiązywania problemów. W Wielkiej Brytanii ma za zadanie docierać do społeczeństwa w różny, zależny od odbiorcy sposób, w celu wzbudzenia jego zainteresowania archeologią (Deskur 2009: 284, 285). W ujęciu Krzysztofa Deskura (2009: 286)

zrozumieć...public archaeology, to odejść od pytania „jak uprawiam archeologię?" w stronę pytań: po co?, dlaczego?, dla kogo?"W grę wchodzą relacje ze światem zewnętrznym, do którego trafiają efekty działalności naukowej. Celem jest archeologia i dziedzictwo archeologiczne pełniące funkcje ważnego elementu kultury oraz partnerskie relacje pomiędzy naukowcami i nie-archeologami (Deskur 2009: 290) ${ }^{12}$.

11 Dla Zalewskiej (2012: 63) rozwój tej gałęzi archeologii to metoda na lepszą ochronę dziedzictwa; Patrz też (Stobnicka 2018: 86-89).

12 Należy przywołać tak piętnowany przez Lecha Czerniaka (2011: 179-180), charakterystyczny dla wykopalisk miejskich, płot kryjący teren badań. W ujęciu badacza stanowi on symbol granicy między archeologami (profesjonalistami) a społeczeństwem (nieprofesjonalistami). 
Duże zapotrzebowanie na wiedzę archeologiczną wiąże się jednak też z niebywałą odpowiedzialnością, gdyż zainteresowanie nią wynika często z postrzegania dziejów przez pryzmat tajemniczości (Pawleta 2011:88). Następuje niebezpieczna mitologizacja przeszłości, prezentowanej bez negatywnych aspektów (Kobiałka 2011: 137; Pawleta 2011: 90). Prowadzi to zdaniem Kobiałki (2011:139) do „powstawania stereotypowego, fałszywego obrazu archeologii".

W kontekście złych doświadczeń historycznych istotne jest, aby społeczna potrzeba zyskania informacji o polu działania i możliwościach, jakie oferują badania archeologiczne, nie była podbudowana chęcią osiągnięcia własnych, nieetycznych celów. Bowiem badania naukowe, $w$ tym te z zakresu nauk humanistycznych, w poprzednim stuleciu narażone były na oddziaływania ideologiczne (Gediga 2004: 213; Kobyliński 2007: 357-360) $)^{13}$.W przypadku archeologii polskiej przejawiało się to $\mathrm{w}$ formie nacisków na zgłębianie zagadnienia pochodzenia Słowian oraz poziomu ich kultury (Gediga 2004: 214, 216, 217) ${ }^{14}$. W związku z tym można zaryzykować stwierdzenie, iż społeczeństwo uznawało pragmatyczny charakter archeologii jako nauki, która pozwalała np. potwierdzić prawa państwa polskiego do ziem zachodnich. W tej sytuacji, jak stwierdził Bogusław Gediga (2004: 214), archeologia, spełniając oczekiwania społeczne, realizowała również własne naukowe cele poznawcze ${ }^{15}$.

Wraz z przemianami ustrojowymi nastąpiła całkowita zmiana priorytetów społeczeństwa polskiego, a co za tym idzie - kwestie ważkie kilka dekad wcześniej nie budzą już takich (lub nawet żadnych) emocji. Podstawowym czynnikiem wpływającym obecnie na pracę naukową są finanse (Zalewska 2011: 122) ${ }^{16}$, a także widoczna również na tym polu wszechobecna presja czasu. Nie bez znaczenia jest również nacisk na utylitarny charakter badań ${ }^{17}$. Wszystkie te wymogi sprawiają, że wykopaliska archeologiczne stanowią obszar chętnie eliminowany $z$ uwagi na drugorzędne znaczenie dla

${ }^{13}$ W opinii Anny Zalewskiej $(2011: 121,122)$ w efekcie wpływów politycznych na archeologię również tę dziedzinę objął problem braku społecznego zaufania wynikający z rozczarowania i nieufności. ${ }^{14}$ Według Michała Pawlety (2011: 91) obecnie możemy mieć do czynienia z pewnego rodzaju oczekiwaniami co do przeszłości płynącymi ze strony Unii Europejskiej.

${ }_{15}$ Przemysław Urbańczyk (2000: 52-53, za Kobyliński 2007: 361) charakteryzuje ówczesne środowisko archeologów jako wykorzystujące możliwości rozwoju nadarzające się w tamtym układzie politycznym i nie wiąże tego faktu z fałszowaniem wymowy źródeł.

${ }^{16}$ Analizy tego problemu podjął się Zbyszko Melosik (2009: 73). Według badacza następuje komercjalizacja uniwersytetu i promowanie czynnika ekonomicznego. Zasada ta dotyczy również wiedzy, stąd nie stanowi już ona źródła prawdy i mądrości tylko towar.

${ }_{17}$ Według Zbyszko Melosika (2009: 73) docenia się dziedziny przynoszące zyski. Badacz nawiązuje do poglądów Patrici J. Gumport (2000:68, 81-82, 84, za Melosik 2009: 75), wskazując, że „w przeszłości wiedza postrzegana była przez pryzmat »skumulowanego społecznego dziedzictwa« oraz jako punkt wyjścia wspólnych wartości i źródło integracji społecznej...współcześnie traktuje się ją w kategoriach rynkowej wartości użytkowej". W efekcie pewne dyscypliny tracą rację bytu, a wiedza nie jest już dobrem publicznym tylko towarem. Podobnie Zbigniew Kubiatowski (2013: 210) porusza kwestię faworyzowania badań, których wyniki mogą mieć realny wpływ na gospodarkę i życie społeczne. Stawia też pytania, jak archeologia może wpływać na te dziedziny? Jego zdaniem rozwiązaniem moga być badania połaczone z propagowaniem ich wyników. Przykładowo prace wykopaliskowe w Wilczycach oraz Chodliku spowodowały interakcję między lokalną społecznością a archeologami. 
społeczeństwa. Ich stała realizacja jest możliwa jedynie dzięki wymogom ustawowym ${ }^{18}$ lub grantom. W dzisiejszych realiach problemu nie stanowi więc już np. kwestia obecności ludów germańskich na ziemiach polskich, ale czas i koszt inwestycji opóźnianej przez prace archeologiczne. Jak więc połączyć realizacje celów badawczych z misją popularyzatorską? Czy w ogóle społeczeństwo ma jeszcze jakieś oczekiwania w stosunku do archeologii?

Dawid Kobiałka, odnosząc się do pracy Corneliusa Holtorfa (2008: 157, za Kobiałka 2011:137), wskazuje na konieczność innego sposobu uprawiania i propagowania archeologii, która ma odpowiadać na potrzeby współczesnego, zmieniającego się społeczeństwa. Dobry efekt może dać łączenie przekazywania wiedzy z kreowaniem pozytywnego wizerunku archeologii (Holtorf 2008: 150, 151, 152, 157) ${ }^{19}$. Najlepszym sposobem na jego budowanie jest własna postawa otwarta na odbiorcę (Holtorf 2008: 162). Ten aspekt wydaje się więc kluczowy. Niezbędne jest - kolokwialnie mówiąc - wyjście do ludzi i uświadomienie im potrzeby poznania badanej przez nas materii. W tym miejscu można przytoczyć opinię Melosika, według którego uniwersytet jako integralna część społeczeństwa musi mu służyć, np. w rozwiązywaniu bieżących problemów, i odpowiadać na pojawiające się potrzeby. Szczególnie jest to istotne w przypadku badań "społecznie bezużytecznych", bez natychmiastowych efektów, czyli z zakresu nauk humanistycznych, których dalekosiężny cel stanowi,,kumulowanie dziedzictwa kulturowego" (Melosik 2009: 80, 81). Według Zalewskiej $(2011: 116,123)$ podstawę do poznania przeszłości dają jej materialne pozostałości, które budzą fascynację, tęsknotę za tym, co minęło, chęć zysku, destrukcji lub są przedmiotem badań specjalistów. Dla badaczki istotne jest również, że archeologia pozwala na „zmaterializowanie" przeszłości i daje szanse na dyskurs społeczny na jej temat. $Z$ drugiej jednak strony Zalewska (2011: 123) zaleca "by zaniechać charakteryzowania archeologii wyłącznie poprzez badania wykopaliskowe i zajmowanie się pradziejowymi danymi. Rekomendowane jest więc skupienie się na interakcji między kulturą materialną i zachowaniem ludzkim, niezależnie od czasu i miejsca, w jakim daje się ona zaobserwować". Natomiast zdaniem Lecha Czerniaka (2011:180) siła przekazu oraz szansa na dotarcie do odbiorcy leży w praktyce uprawiania archeologii. Autor wyróżnił model autorytatywny oraz społeczny. Pierwszy można postrzegać jako klasyczny, w którym za ochronę dziedzictwa odpowiada państwo, a popularyzacją archeologii zajmuje się muzeum. W drugim, gdy angażowane są środki prywatne, istotnym elementem staje się aktywność społeczna. Podstawę „stanowi popularyzacja archeologii (społeczna edukacja)", prowadzona również podczas prac wykopaliskowych ${ }^{20}$.Zdaniem Czerniaka (2011: 181) model społeczny realizowany jest $w$ archeologii brytyjskiej, natomiast

\footnotetext{
${ }_{18}$ Ustawa z dnia 23 lipca 2003 r. o ochronie zabytków i opiece nad zabytkami, Dz.U. z 2003 r. Nr 162, poz. 1568, art. 3, pkt 4; art. 6, pkt 3, art. 7, art. 8, art. 31.

${ }^{19}$ Te modele współegzystują i mogą być $w$ różnym stopniu łączone.

${ }^{20}$ Czerniak (2011: 182, 183) uważa wręcz, że:„najważniejszym polem współczesnej edukacji są wykopaliska...odpowiednia prezentacja wykopalisk może dostarczyć najważniejszego doświadczenia, kreującego pozytywny stosunek społeczeństwa do dziedzictwa archeologicznego".
} 
w polskiej pokutuje autorytatywny. Temu podejściu przeczy jednak omówiony poniżej przykład (Kajda, Kostyrko 2016: 12-18).

Popularyzacja w Polsce opiera się na festiwalach archeologicznych, publikacji artykułów popularnonaukowych, w mniejszym stopniu na wolontariacie podczas prac wykopaliskowych (Kajda, Kostyrko 2016: 10). Tego typu działania nie są jednak poprzedzone badaniami, które informowałyby o oczekiwaniach społeczności lokalnej względem archeologów. Stąd też nie jest znana skuteczność oraz wpływ tych przedsięwzięć na zwiększanie świadomości archeologicznej. Kornelia Kajda i Mikołaj Kostyrko, propagując ideę nauki otwartej na społeczeństwo przez realizację postulatów archeologii zaangażowanej społecznie, archeologów wsłuchanych w głos lokalnej społeczności i współpracujących z nią dla obopólnych korzyści (Kajda, Kostyrko 2016: 12-18), zaproponowali badania społeczne przed wykopaliskami, lekcje i pogadanki na stanowisku archeologicznym w trakcie ekspedycji i konferencję kierowaną do lokalnej społeczności po zakończeniu prac. Przeprowadzona przed badaniami ankieta wykazała, że 54\% respondentów oczekuje współpracy pomiędzy archeologami a społeczeństwem, które jest zainteresowane rezultatami ich prac, zwłaszcza gdy je finansuje (Kajda, Kostyrko 2016: 17). Przeważająca część pytanych preferowała spotkania $\mathrm{z}$ archeologiem, np. na stanowisku, część była zainteresowana wolontariatem podczas badań.

Dla odbiorców działań popularyzatorskich równie istotny jak sam zakres badań jest interesujący, nowatorski i przystępny sposób ich prezentacji. W innym przypadku informacje przekazywane społeczeństwu, nawet gdy dotyczą spektakularnych odkryć, mogą nie zostać zrozumiane (Pawleta 2016b: 395; Kajda i in. 2017: 19, 20). Europejskie badania oparte na ankietach wykazały, że dla większości społeczeństwa kontakt z archeologią może zostać zrealizowany przez zwiedzenie stanowisk archeologicznych (85\%), spotkanie $z$ archeologiem (62\%), udział w wykopaliskach (61\%) (Kajda i in. 2017: 17; Kajda, Pawleta, Marciniak 2017: 77, 78). Z tych trzech postulatów pierwszy i ostatni nie jest wykonalny w realiach wykopalisk miejskich (takich jak te na Targu Siennym), prowadzonych czasami łącznie z budową (Wołyńska 2018: 75, 76). Natomiast drugi związany z propozycjami lepszego rozpowszechniania rezultatów badań i tworzenia liczniejszych opcji współpracy (71\%) (Kajda i in. 2017: 17) jest możliwy do wprowadzenia w życie.

Specyficzny przykład wskazanych problemów stanowi praca archeologa-badacza w firmie prywatnej. W przeciwieństwie do działalności na uniwersytecie czy w muzeum nie jest on w stanie całkowicie poświęcić się aktywności naukowej i edukacyjnej lub popularyzatorskiej. Natomiast firma archeologiczna, mimo prowadzenia badań wykopaliskowych analogicznych do tych realizowanych przez instytucje, nie jest tak jak muzeum ograniczona ustawą ${ }^{21}$ i ma z założenia generować zysk. Tego typu sytuacja powoduje często problemy natury etycznej. Duża konkurencja na rynku zmusza właścicieli firm do znacznego obniżania kosztów. Brak funduszy sprawia, że aspekt

${ }^{21}$ Ustawa z dnia 21 listopada 1996 r. o muzeach, Dz.U.z 1997 r. Nr 5 poz. 24, art. 2, pkt 2, 7, 8, 10; art. 9. 
naukowy, czyli właściwy cel wykopalisk, jest często pomijany (Gediga 2011: 165-166; Jaszewska 2013: 181-182). Mimo wymogów formalnych przeważnie brak jest publikacji prezentujących wyniki badań. Zastępują je lakoniczne sprawozdania, stanowiące realny, lecz niezadowalający wynik przeprowadzonych prac (Gołębnik, Grubka 2005; 2006: 62). W archeologii komercyjnej osiąganie efektów naukowych stanowi jedynie (w wyjątkowych przypadkach aż) o rzetelności badawczej, a więc często nie jest głównym celem podjętych prac terenowych.

\section{Studium przypadku - archeologiczne doświadczenia z Targu Siennego}

Skala i różnorodność odkryć dokonanych w trakcie ekspedycji na Targu Siennym stanowiła asumpt do przedstawienia wybranych zagadnień podczas kilku konferencji ${ }^{22}$ (ryc. 10,11) i licznych wystąpień. Prelekcje stały się sposobem na kształtowanie w społeczeństwie gdańskim świadomości potrzeby badań archeologicznych i niwelowanie czynników wpływających na negatywny wizerunek tej dziedziny. Cel był realizowany dzięki udanemu połączeniu pracy zawodowej z aktywnością naukową i edukacyjną. Działalność popularyzatorska prowadzona była przez autorkę z własnej inicjatywy, ale również w ramach obowiązków służbowych. Te dwa aspekty udało się powiązać w przypadku festynu ${ }^{23}$ "Zamieszanie u Flinstonów" organizowanego w Szkole Podstawowej nr 52 im. Tadeusza Kościuszki w Gdańsku. Organizatorzy przyjęli formułę nauki przez zabawę. O udział poproszono firmę archeologiczną reprezentowaną przez autorkę. Działania popularyzatorskie polegały na zorganizowaniu „kiosku archeologicznego", w którym omawiane były wybrane zabytki archeologiczne oraz droga, jaką przebywają od stanowiska archeologicznego do muzealnej gabloty (ryc. 12).

\footnotetext{
${ }^{22}$ Marta Wołyńska, Gdańskie dziedzictwo archeologiczne a wielkie inwestycje, trzy dekady zmagań, „III Ogólnopolska Konferencja Studencko-Doktorancka. Rozpoznać przeszłość w teraźniejszości, dziedzictwo w obliczu transformacji, Kraków 21-22 kwietnia 2017"; Marta Wołyńska, Gdańsk tableware - chosen pottery vessels from excavation of Targ Sienny, "Trzecie Międzynarodowe Sympozjum Ceramiki i Szkła OSTRAKON "Ceramika i szkło w badaniach interdyscyplinarnych", Wrocław, 27-29 wrzesień 2017, Polska"; Marta Wołyńska, Tokeny a prace drogowe w XVI-wiecznym Gdańsku, „XXI SESJA POMORZOZNAWCZA za lata 2016-2017, Toruń 22-24 listopada 2017".

${ }^{23}$ Autorka postanowiła propagować archeologię w takiej formie mimo rozbieżnych opinii środowiska badaczy na temat jej przydatności (czy wręcz szkodliwości). Dla Lecha Czerniaka (2011: 182) festyn to przejaw tzw. archeologii ludycznej, dopuszczalny jako jeden ze środków popularyzacji, w innych zastosowaniach grożący uproszczeniem przekazu. Również Wojciech Brzeziński (2000: 153, za Pawleta 2011: 93) mówi o „banalizacji pokazów i przestrzega też przed dominacją rozrywki nad popularyzacją". Natomiast Łukasz M. Dominiak (2004: 83-84, za Pawleta 2011: 94) porównuje festyn archeologiczny do „karnawałowego święta”. W prezentowanym przypadku nie był to jednak festyn typowo archeologiczny, więc popularyzacja, jako jedna z atrakcji, przybierała formę pogadanki oraz dialogu z odbiorcą.
} 


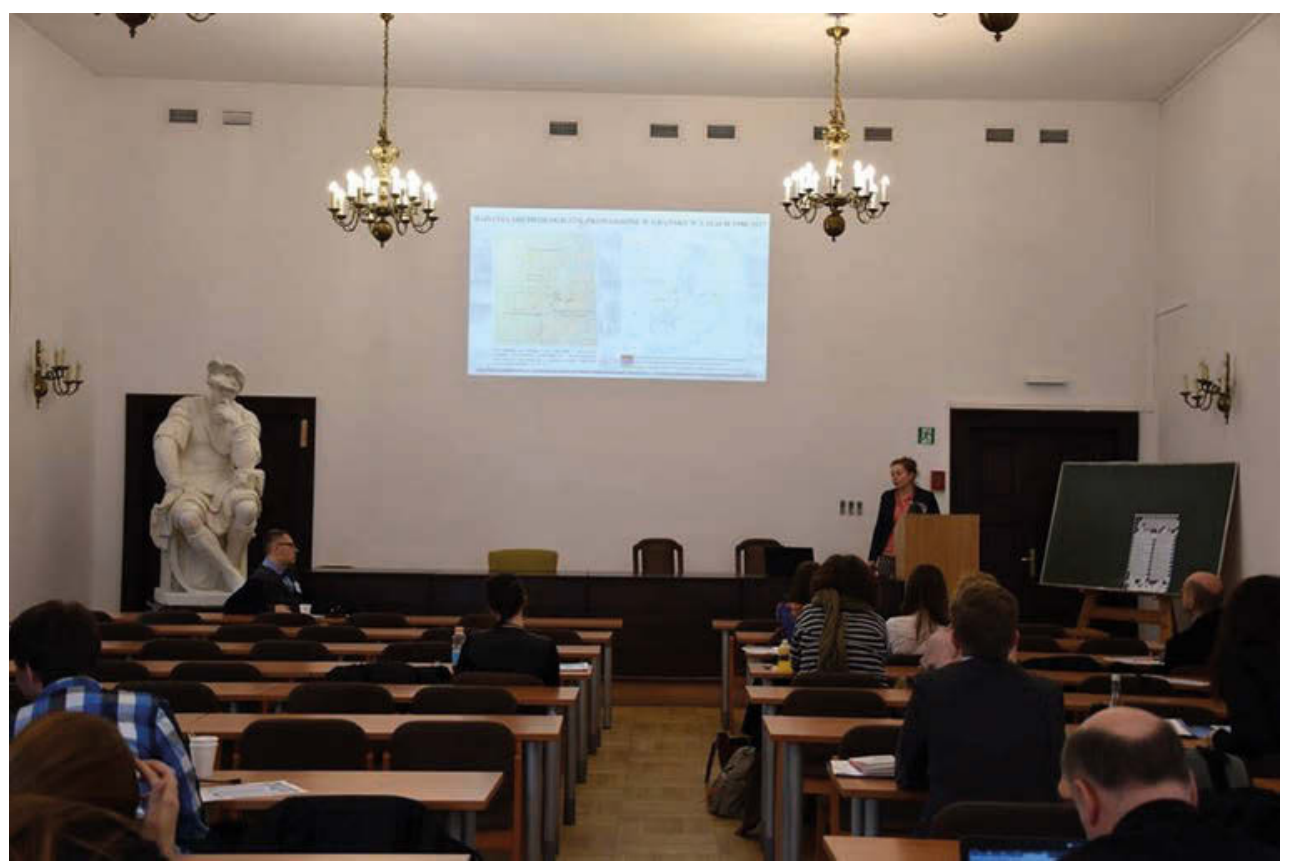

10. „IIII Ogólnopolska Konferencja Studencko-Doktorancka. Rozpoznać przeszłość w teraźniejszości, dziedzictwo w obliczu transformacji.,', Kraków 2017 (fot. Jadwiga Kolasińska)

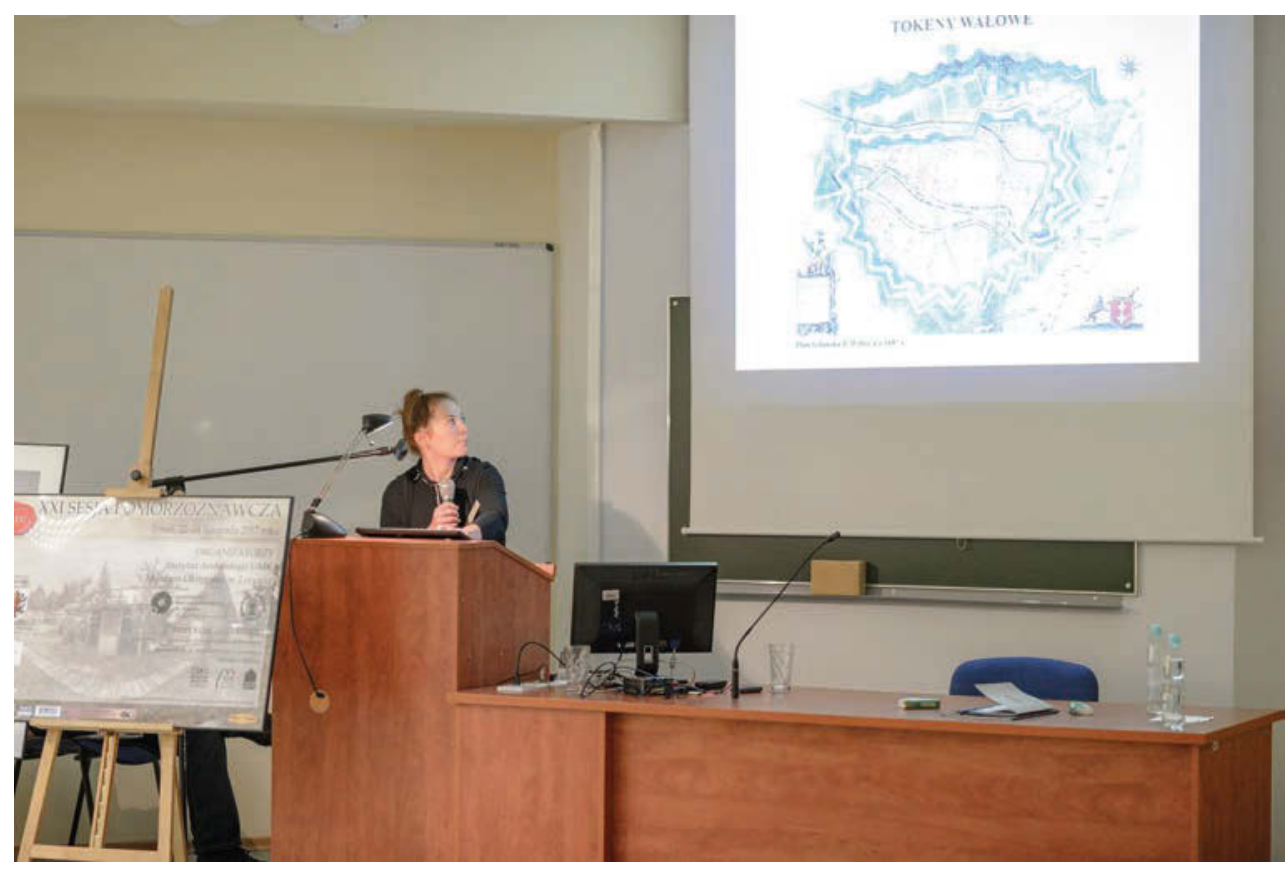

11. „XXI Sesja Pomorzoznawcza”, Toruń 2017 (fot. Wiesław Ochotny) 


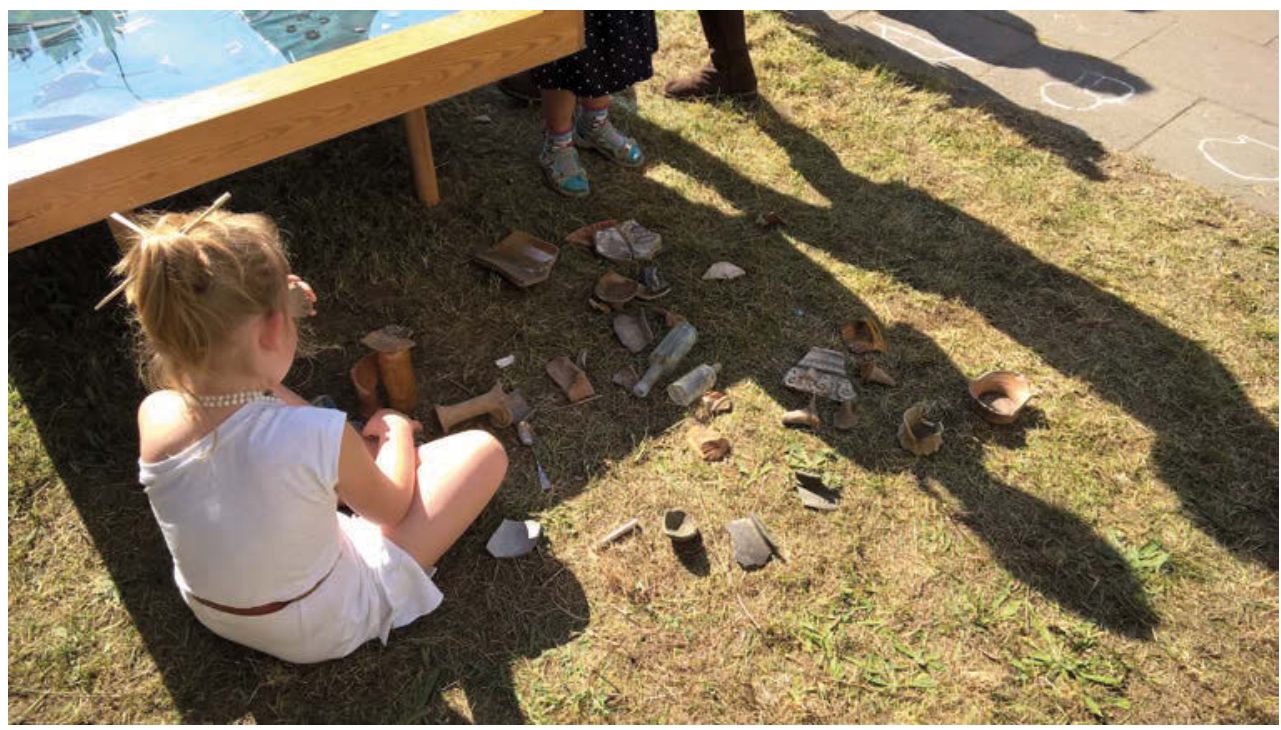

\section{Festyn „Zamieszanie u Flinstonów”, Gdańsk 2017 r. (fot. Marta Wołyńska)}

Prezentacja przedmiotów z życia codziennego sprzed kilku stuleci stanowiła również punkt wyjścia do przedstawienia rozmaitych, zanikających rzemiosł. Ukazane zostały one przy zastosowaniu puzzli wykonanych z ilustracji z Hausbuch der Mendelschen... Bd. 1 i 2, oraz Hausbuch der Landauerschen...Bd. 1, wyobrażających przedstawicieli różnych zawodów (ryc. 13). Po ułożeniu puzzli należało omówić pracę prezentowanego rzemieślnika. Poprawna odpowiedź była promowana otrzymaniem jednej ze sprawności, kolekcjonowanych przez uczestników imprezy. Rozpoczynając od omówienia pozyskanych na wykopaliskach narzędzi, można było dojść od przedmiotów do rzemiosł znanych już wyłącznie z realiów etnograficznych. W ten sposób podjęta została próba prezentacji dziedzictwa materialnego w kontekście historycznym, z którego zostało ono wyrwane. Poznanie kultury naszych poprzedników, ich dokonań oraz trudów codziennej egzystencji miało na celu zrozumienie ich mentalności. Takie działanie ma umożliwiać budowanie tożsamości lokalnej ${ }^{24}$. Dzieci i młodzież to grupa odbiorców szczególnie istotna w świetle badań ankietowych, które wykazały mniej pozytywny stosunek do archeologii w grupie młodszych polskich czy szwedzkich respondentów (poniżej 35 roku życia). Jednocześnie sami ankietowani przypisywali archeologii głównie rolę edukacyjną (Kajda i in. 2017: 16, 17).

\footnotetext{
${ }^{24}$ Kinga A. Gajda (2016: 290, 291) odnosi się do artykułu Charlotte Linde (2000: 608-632) i za badaczką twierdzi, że obecnie opowiadanie o dziedzictwie staje się „aktem budowania przynależności do przeszłości i tożsamości lokalnej. Aby bowiem być członkiem danej społeczności, należy opowiedzieć jej historię".
} 


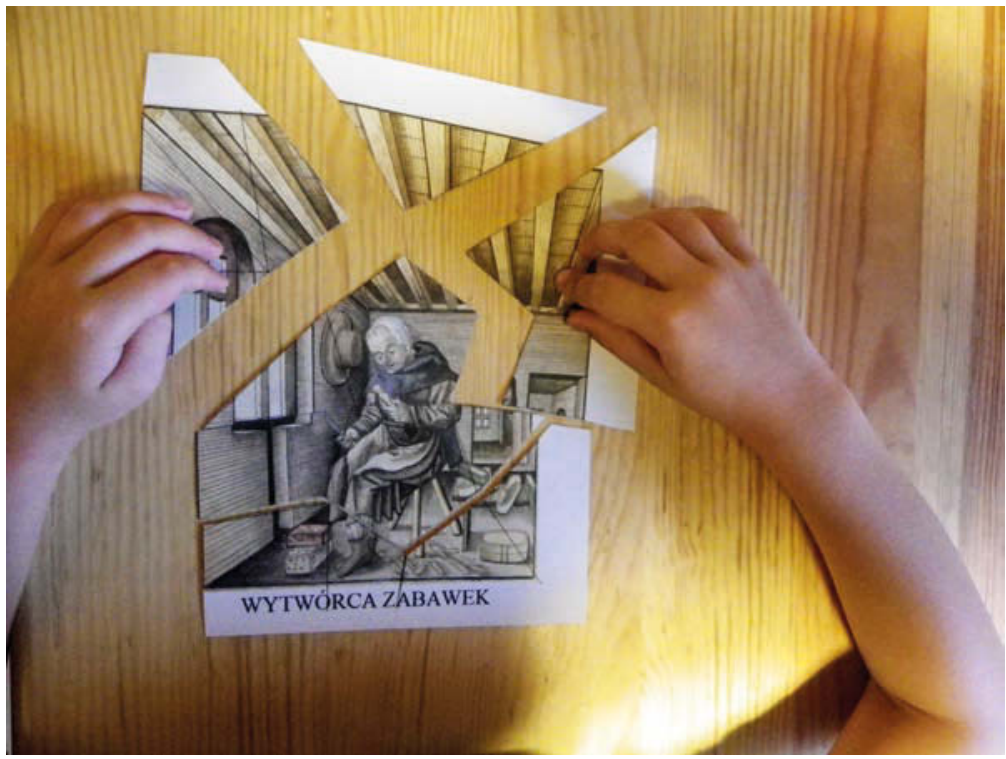

13. Układanie puzzli z ilustracji z Hausbuch der Mendelschen...Bd. 2, Amb. 317b. $2^{\circ}$ Folio 10 verso (1558 r.)

Inną metodę popularyzacji stanowiła współpraca - podjęta jeszcze w trakcie prac prowadzonych na Targu Siennym - z Wojewódzką i Miejską Biblioteką Publiczną im. Josepha Conrada-Korzeniowskiego w Gdańsku. W jej efekcie, w ramach Doktowykładów ${ }^{25}$ zostały zaprezentowane odkrycia: piwnic Senatu Wolnego Miasta Gdańska ${ }^{26}$ (ryc. 14, 15), czy pierwszej gdańskiej elektrowni tramwajowej, zlokalizowanej na Targu Rakowym ${ }^{27}$ (ryc. 16). Wykłady cieszyły się dużym zainteresowaniem. Frekwencja sięgała od 20 do około 50 osób. Po zakończeniu etapu prac terenowych nadszedł moment na całościową prezentację wyników badań. Zadanie to było realizowane równolegle w zakresie specjalistycznym, jak i popularnonaukowym. Te dwie formy relacji zostały zaprezentowane w Muzeum Historycznym Miasta Gdańska ${ }^{28}$ (ryc. 17, 18). Kolejne prelekcje o charakterze naukowym przedstawiane były przez pracowników firmy Dantiscum we współpracy z Uniwersytetem Wrocławskim oraz Instytutem Archeologii i Etnologii PAN w Warszawie. Jako największe osiągnięcie można jednak uznać

${ }^{25}$ Projekt Doktowykłady, czyli humanistyka oczami młodych naukowców, to cykl fakultatywnych spotkań zainicjowanych i prowadzonych przez uczestników Filologicznych Studiów Doktoranckich Uniwersytetu Gdańskiego. Spotkania są okazją do prezentacji różnorodnych punktów widzenia na problemy współczesności, pozwalają także na kształtowanie postawy otwartości oraz promowanie współczesnej humanistyki (http://www.wbpg.org.pl/aktualnosc/doktowyk\%C5\%82ady z dnia 05.08.2018).

${ }^{26}$ Marta Wołyńska, „Tajemnice piwnic Senatu Wolnego Miasta Gdańska". Relacja z badań archeologicznych, 28 stycznia $2016 \mathrm{r}$.

${ }_{27}$ Marta Wołyńska, Relikty elektrowni tramwajowej na Targu Rakowym. Rozwój Gdańska u schyłku XIX wieku w świetle źródeł archeologicznych, 16 lutego $2017 \mathrm{r}$.

28 "Targ Sienny w Gdańsku w świetle najnowszych badań archeologicznych": Alicja Gomoliszek, Marta Wołyńska, Badania archeologiczne na Targu Siennym w Gdańsku; Joanna Jarzęcka-Stąporek, Paulina Terendy, Cmentarzysko Szpitala świętej Gertrudy w Gdańsku w świetle wykopalisk. 
organizację wystawy czasowej pt. „Targ Sienny w Gdańsku - przedmieście europejskiej metropolii - w świetle wykopalisk archeologicznych", prezentowanej w Ratuszu Głównego Miasta Gdańska od 1 czerwca do 31 października 2016 r. Stanowiła ona efekt udanej kooperacji firmy prywatnej i instytucji - Muzeum Historycznego Miasta Gdańska. Po stronie firmy Dantiscum leżało przygotowanie zabytków oraz strony merytorycznej ekspozycji (ryc. 19, 20). Muzeum zapewniło salę wystawienniczą, gabloty, zajęło się również kwestią ubezpieczenia zabytków. Kuratorami wystawy byli: pracownik muzeum Pani Katarzyna Kurkowska oraz kierownik Pracowni Badań Archeologicznych Dantiscum Pan Robert Krzywdziński. Wystawa, z uwagi na temat, a także ekspozycję w okresie letnim, cieszyła się dużym powodzeniem. Zainteresowanie sprawiło, że zyskała ona dodatkowy atut w postaci zatrudnionego przez muzeum przewodnika. Z uwagi na wspomniany wcześniej regres w zakresie publikacji archeologicznych godny podkreślenia jest fakt, iż po wystawie pozostał materialny ślad w postaci katalogu (Krzywdziński 2016). Stanowi on omówienie wybranych zabytków i daje pewne wyobrażenie o przygotowywanym, całościowym opracowaniu stanowiska na Targu Siennym.

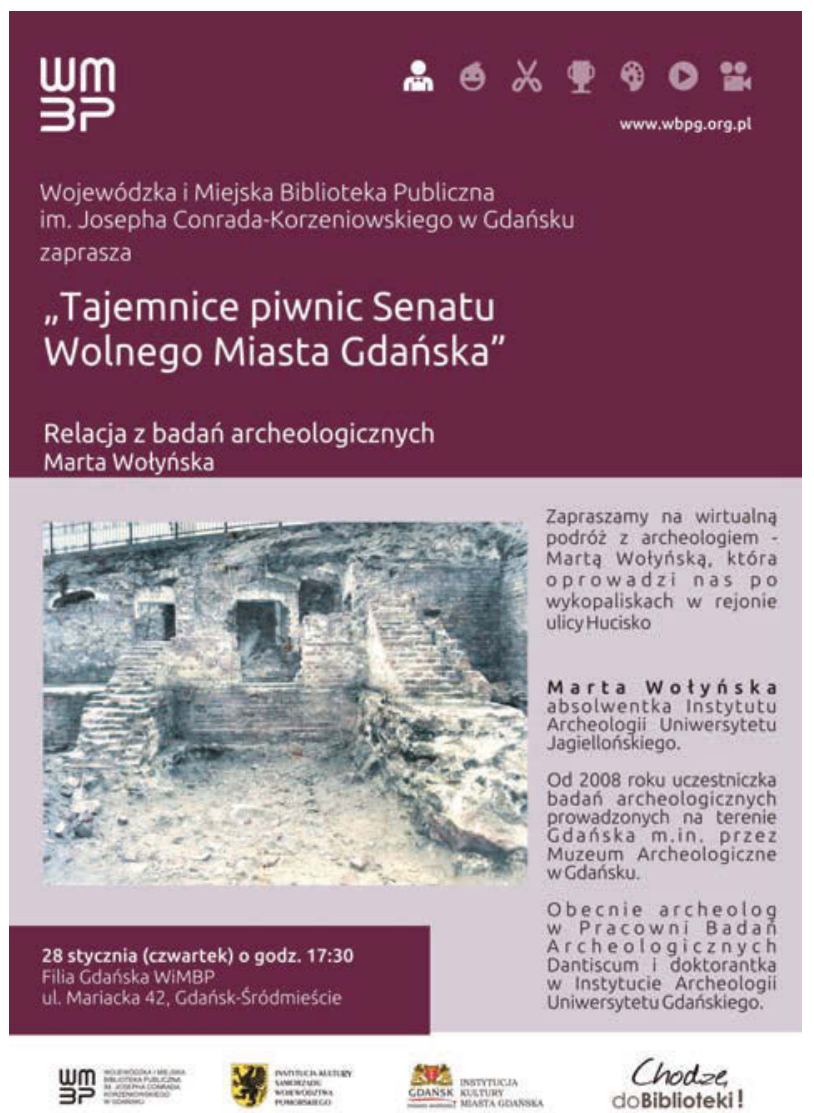

14. Plakat promujący referat „Tajemnice piwnic Senatu Wolnego Miasta Gdańska". Relacja z badań archeologicznych (WiMBP w Gdańsku) 


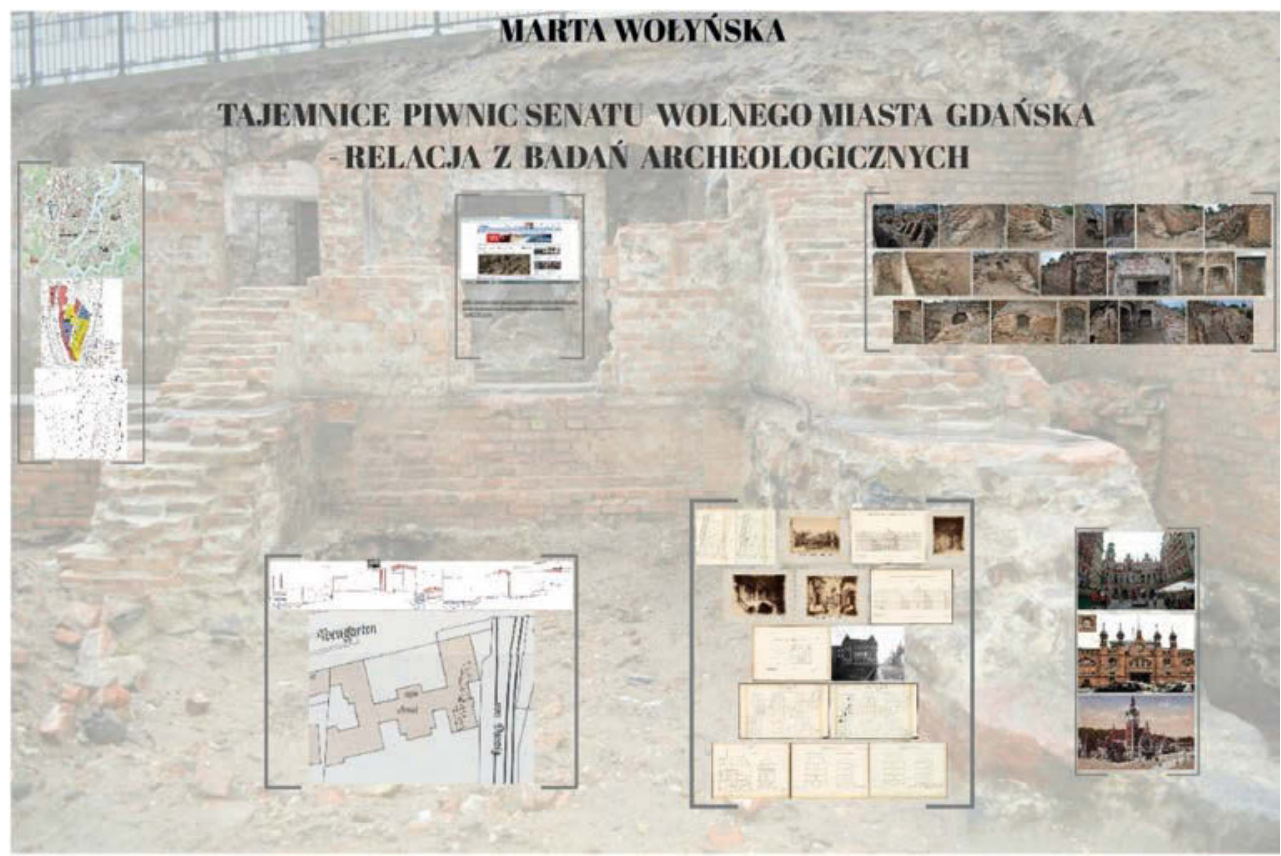

15. Widok prezentacji referatu „Tajemnice piwnic Senatu Wolnego Miasta Gdańska”. Relacja z badań archeologicznych (fot. Marta Wołyńska)

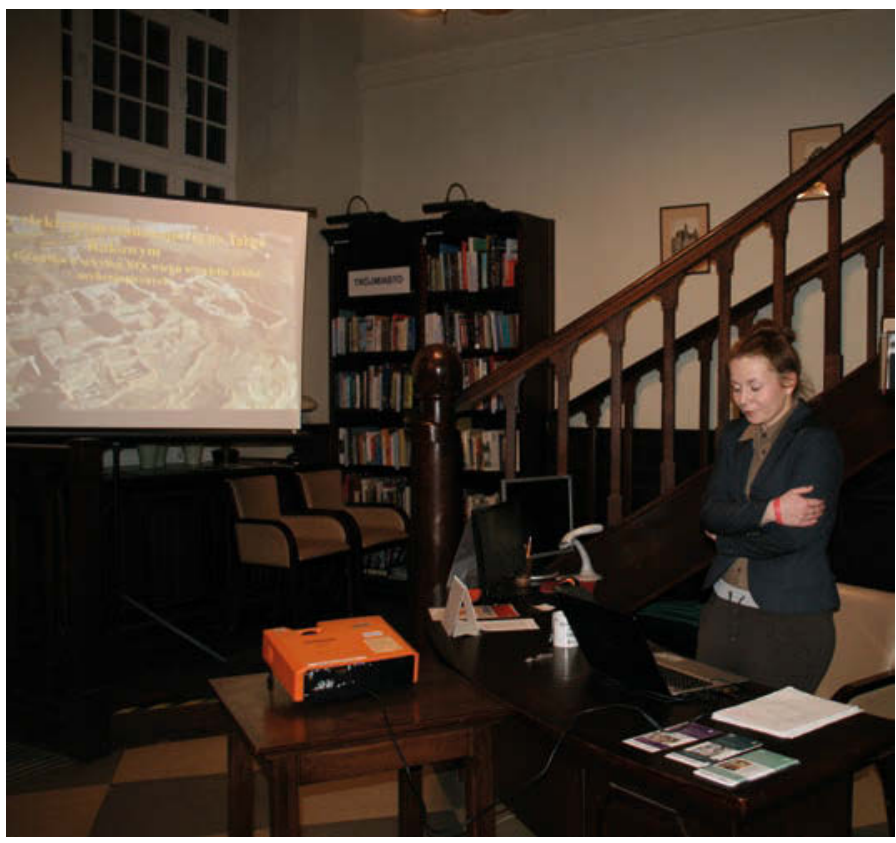

16. Prelekcja Relikty elektrowni tramwajowej na Targu Rakowym. Rozwój Gdańska u schyłku XIX wieku w świetle źródeł archeologicznych (WiMBP w Gdańsku) (fot. Daniela Radowicz-Kmiecik) 


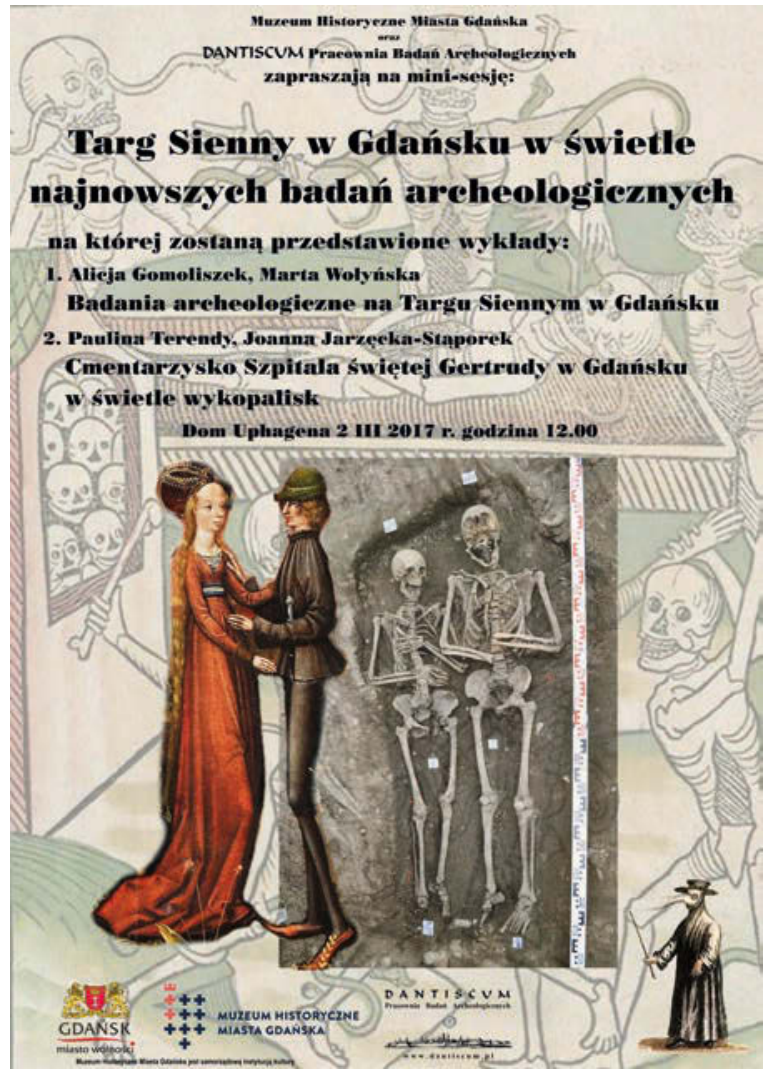

17. Plakat promujący mini-sesję „Targ Sienny w Gdańsku w świetle najnowszych badań archeologicznych" w Muzeum Historycznym Miasta Gdańska (projekt Robert Krzywdziński)

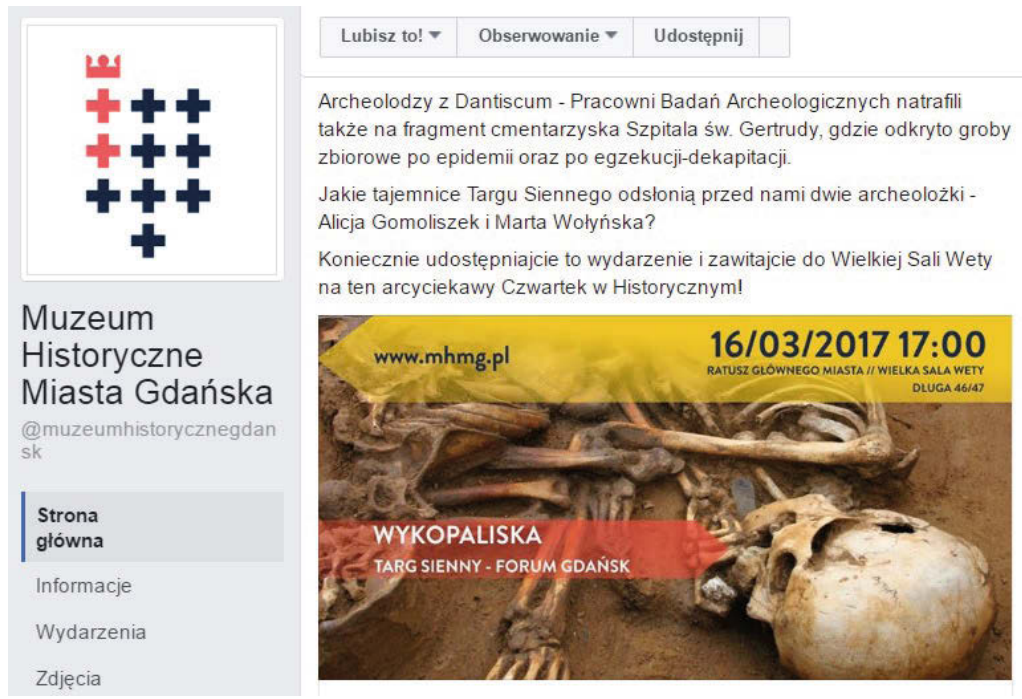

18. Plakat promujący prelekcję w Muzeum Historycznym Miasta Gdańska 


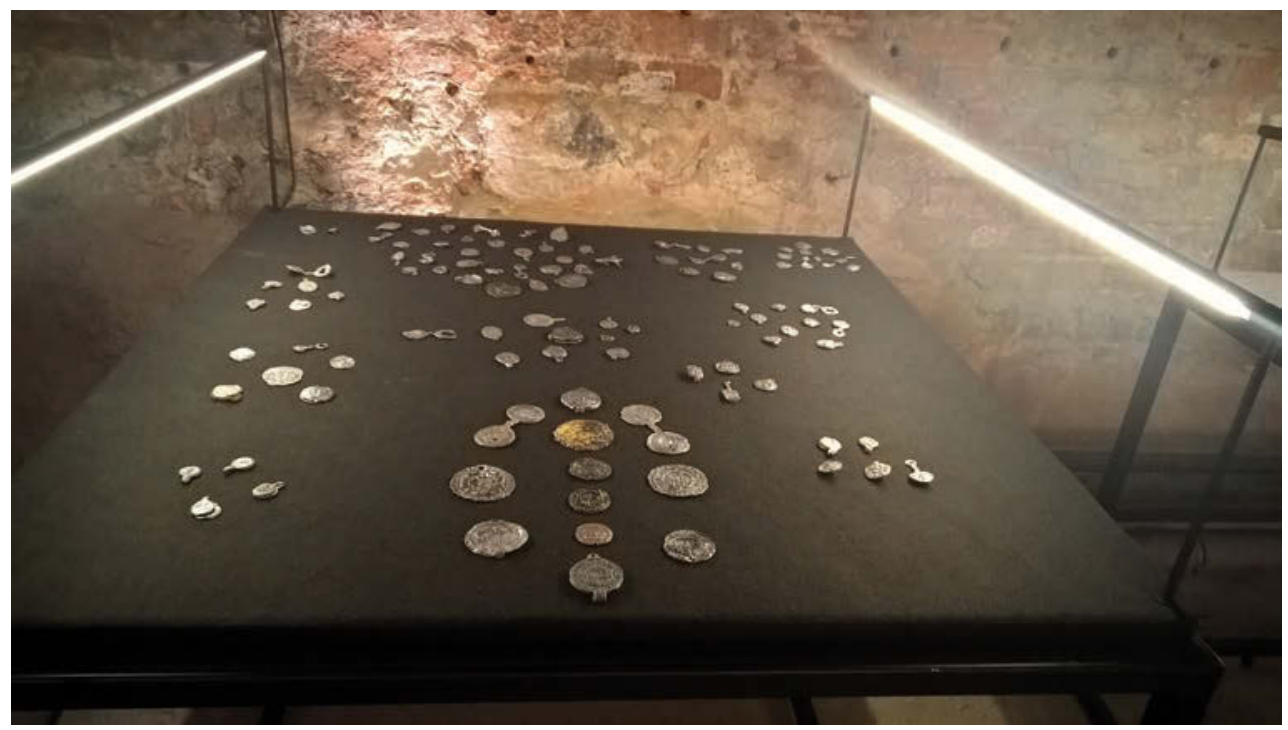

19. Przygotowania wystawy „Targ Sienny w Gdańsku - przed mieście europejskiej metropolii - w świetle wykopalisk archeologicznych", w piwnicy Ratuszu Głównego Miasta Gdańska (fot. Marta Wołyńska)

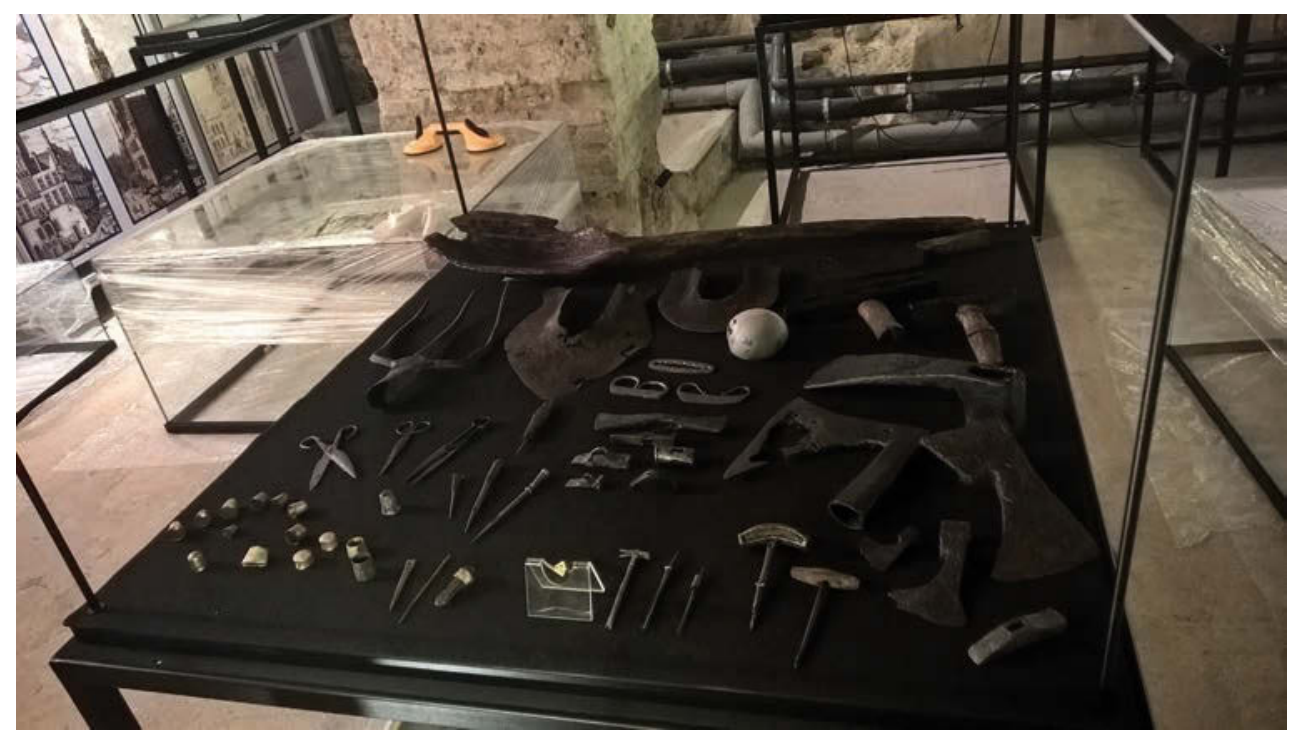

20. Przygotowania wystawy „Targ Sienny w Gdańsku - przed mieście europejskiej metropolii - w świetle wykopalisk archeologicznych", w piwnicy Ratuszu Głównego Miasta Gdańska (fot. Marta Wołyńska) 


\section{Zakończenie}

Wydaje się, że badania archeologiczne prowadzone przez firmę prywatną na Targu Siennym, w ramach inwestycji będącej partnerstwem publiczno-prywatnym, którego stroną jest miasto Gdańsk, stanowią dobry przykład uprawiania archeologii społecznej. W ramach tych prac realizowane były działania popularyzatorskie, takie jak: ćwiczenia dla studentów na terenie wykopalisk czy liczne prelekcje naukowe i popularnonaukowe. Te aktywności to przykład wyraźnego przejścia w kierunku zwiększenia roli edukacji realizowanej poza instytucjami, ale we współpracy z nimi. Prowadzona wielopłaszczyznowo popularyzacja stanowiła okazję do prezentacji zakresu prac, problemów badawczych i logistycznych na szczególnie skomplikowanym stanowisku miejskim. Dała również możliwość unaocznienia mozołu prac gabinetowych równie ekscytujących, ale znacznie bezpieczniejszych niż poszukiwanie zaginionej arki.

\section{Bibliografia}

Ashworth G., 2015, Planowanie dziedzictwa, tłum. M. Duda-Gryc, Kraków: Międzynarodowe Centrum Kultury.

Bauman Z., 2006, Globalizacja. I co z tego dla ludzi wynika, tłum. E. Klekot, Warszawa: Państwowy Instytut Wydawniczy.

Brzeziński W., 2000, Muzea jako instytucje ochrony i prezentacji dziedzictwa archeologicznego [w:] K. Gutkowska (red.), Problemy zarządzania dziedzictwem kulturowym, Warszawa: Res Publica Multiethnica.

Czerniak L., 2011, Dla kogo sq wykopaliska? Profesjonaliści i społeczeństwo [w:] A. Marciniak, D. Minta-Tworzowska, M. Pawleta (red.), Współczesne oblicza przeszłości, Poznań: Wydawnictwo Poznańskie. Deskur K., 2009, Idea public archaeology - edukacja archeologiczna i popularyzacja archeologii ,,Fontes Archaeologici Posnanienses", Tom XLV: Muzeum Archeologiczne w Poznaniu.

Dominiak Ł.M., 2004, Zabawa w przeszłość. Festyn archeologiczny jako forma karnawału [w:] J. Grad, H. Mamzer (red.), Karnawalizacja: tendencje ludyczne w kulturze współczesnej, Poznań: Wydawnictwo Naukowe UAM.

Gajda K.A., 2016, Aktywne metody edukacji muzealnej. Uczenie o niematerialnym dziedzictwie kulturowym [w:] M. Kwiecińska (red.), Niematerialne dziedzictwo miasta muzealizacja, ochrona, edukacja, Kraków: Muzeum Historyczne Miasta Krakowa.

Gediga B., 2004, Poznanie naukowe a społeczne oczekiwania. [w:] B. Gediga, W. Piotrowski (red.), Archeologia kultura ideologie, Biskupin-Wrocław: Muzeum Archeologiczne w Biskupinie.

Gediga B., 2011, Problemy ochrony zabytków archeologicznych w Polsce. [w:] B. Szmygin (red.), System ochrony zabytków w Polsce - analiza, diagnoza, propozycje, Lublin-Warszawa: Polski Komitet Narodowy Międzynarodowej Rady Ochrony Zabytków ICOMOS, Biuro Stołecznego Konserwatora Zabytków Urzędu Miasta Stołecznego Warszawa.

McGimsey C., 1972, Public Archaeology, New York-London: Seminar Press.

Gołębnik A., Grubka M. OP., 2005; 2006 Muzeum pod niebem, „,Muzealnictwo" Rocznik XLVII: Narodowy Instytut Muzealnictwa i Ochrony Zbiorów. 
Gumport P.J., 2000, Academic Restructuring: Organizational Change and Institutional Imperatives, „Higher Education”, Vol. 39: Kluwer Academic Publishers.

Hensel W., 1973, Zakres i zadania archeologii, „Slavia Antiqua”, t. XX : Poznańskie Towarzystwo Przyjaciół Nauk, Instytut Prahistorii UAM.

Holtorf C., 2008, Can you hear me at the back? Archaeology, communication and society , European Journal of Archaeology", Vol. X (2-3): Cambridge University Press.

Jaszewska A., 2013, Badania archeologiczne - usługa czy badania naukowe? [w:] A. Jaszewska A. (red.), Sesja tematyczna 11. Zawód archeologa w Polsce. Stan obecny i perspektywy, „Pierwszy Kongres Archeologii Polskiej, Warszawa, 19-21 września 2013 roku”, Warszawa : Zarząd Główny Stowarzyszenia Naukowego Archeologów Polskich.

Kajda K., 2013, Archeologia i społeczeństwo. O postrzeganiu archeologów i ich współpracy ze społecznościq lokalnq, [w:] S. Zdziebłowski (red.), Sesja tematyczna 14. Komunikacja społeczna w archeologii, „Pierwszy Kongres Archeologii Polskiej, Warszawa, 19-21 września 2013 roku”, Warszawa : Zarząd Główny Stowarzyszenia Naukowego Archeologów Polskich.

Kajda K., Kostyrko M., 2016, Contemporary Dimension of Heritage Promotion - Towards Socially Engaged Archaeology, ",Sprawozdania Archeologiczne", t. LXVIII : Instytut Archeologii i Etnologii Polskiej Akademii Nauk.

Kajda K., Marx A., Wright H., Richards J., Marciniak A., Salas Rossenbach K., Pawleta M., Dries van den M.H., Boom K., Guermandi M.P., Criado-Boado F., Barreiro D., Synnestvedt A., Kotsakis K., Kasvikis K., Theodoroudi E., Lüth F., Issa M., Frase I., 2017, Archaeology, Heritage and Social Value. The Public Perspectives on European Archaeology.,,"European Journal of Archaeology”, Tom XXI : Cambridge University Press.

Kajda K., Pawleta M., Marciniak A., 2017, Archeologia, dziedzictwo archeologiczne i ich społeczne znaczenie w oczach współczesnych Polaków. „Folia Praehistorica Posnaniensia”, t. XXII: Wydawnictwo Naukowe UAM.

Kobiałka D., 2011, Społeczny wizerunek archeologii-o rzeczywistości w fikcji [w:] A. Marciniak, D. Minta-Tworzowska, M. Pawleta (red.), Współczesne oblicza przeszłości, Poznań: Wydawnictwo Poznańskie. Kobiałka D., 2013, Archeologia Józefa Kostrzewskiego z perspektywy współczesnej refleksji metodologicznej. Praca doktorska napisana pod kierunkiem Prof. UAM dr hab. Włodzimierza Rączkowskiego, Poznań (praca niepublikowana).

Kobyliński Z., 2007, Archeologia wczesnego średniowiecza w Polsce 1939-1989: sukcesy i porażki. [w:] J. Lech (red.), Pół wieku z dziejów archeologii polskiej (1939-1989), Warszawa: Wydawnictwo Naukowe PWN.

Kobyliński Z., 2010, Archeologia polska na początku XXI wieku - szanse i zagrożenia [w:] M. Przybyła, M. Winiarska-Kabacińska (red.), Archeologia wobec wyzwań współczesności, Poznań: Wydawnictwo Poznańskiego Towarzystwa Przyjaciół Nauk.

Krzywdziński R., red., 2016, Targ Sienny w Gdańsku - przedmieście europejskiej metropolii - w świetle wykopalisk archeologicznych. Katalog wystawy prezentowanej w Ratuszu Głównego Miasta w Gdańsku w okresie od 1 czerwca do 25 września 2016 roku, Gdańsk: Muzeum Historyczne Miasta Gdańska.

Kubiatowski Z., 2013, Między panem, wójtem i plebanem - wpływ kontaktów z lokalna społecznością na badania archeologiczne na przykładzie prac wykopaliskowych w Wilczycach i Chodliku [w:] A. Jaszewska (red.), Sesja tematyczna 11. Zawód archeologa w Polsce. Stan obecny i perspektywy, ,Pierwszy Kongres Archeologii Polskiej, Warszawa, 19-21 września 2013 roku", Warszawa: Zarząd Główny Stowarzyszenia Naukowego Archeologów Polskich. 
Linde C., 2000, The acquisition of a speaker by a story: How history becomes memory and identity „,Ethos: Special Issue on History and Subjectivity", No. XXVIII: Society for Psychological Anthropology; American Anthropological Association.

Malinowski T., 2016, (rec.) M. Kalisz-Zielińska, Józef Kostrzewski jako prekursor edukacji muzealnej w Polsce po Il wojnie światowej [w:] A. Pihan-Kijasowa, D. Konieczka-Śliwińska (red.) Nie zgaśnie pamięć o Waszej pracy. Założyciele Uniwersytetu Poznańskiego, Poznań 2016, "Materiały i Sprawozdania Rzeszowskiego Ośrodka Archeologicznego", t. XXXVII, Rzeszów: Instytut Archeologii Uniwersytetu Rzeszowskiego.

Melosik Z., 2009, Uniwersytet a społeczeństwo. Dyskursy wolności, wiedzy i władzy, Kraków: Impuls.

Od redakcji, 1926, Od redakcji „,Z Otchłani Wieków”, Rocznik 1: Stowarzyszenie Naukowe Archeologów Polskich.

Pawleta M., 2011, Przeszłość we współczesności [w:] A. Marciniak, D. Minta-Tworzowska, M. Pawleta, red., Współczesne oblicza przeszłości, Poznań: Wydawnictwo Poznańskie.

Pawleta M., 2016a, Przeszłość we współczesności. Studium metodologiczne archeologicznie kreowanej przeszłości w przestrzeni społecznej, Poznań: Wydawnictwo Naukowe UAM.

Pawleta M., 2016b, Upowszechnianie dziedzictwa archeologicznego regionu Bobolic: realizacje i propozycje „,Folia Praehistorica Posnaniensia”, t. XXI: Wydawnictwo Naukowe UAM.

Radziszewska M., 2009, Wspomnienie o Józefie Kostrzewskim w 40. rocznicę śmierci nestora polskiej archeologii, ,_Pro Libris” nr 4 (29), Zielona Góra: Pro Libris.

Stobnicka M., 2018, Niewidzia(I)na rewolucja? Transformacja i jej wpływ na popularyzację archeologii [w:] J. Kolano, J. Kolasińska (red.), Rozpoznać przeszłość w teraźniejszości. Dziedzictwo w obliczu transformacji, Kraków: Akademickie Koło Studentów Ochrony Dóbr Kultury Uniwersytetu Jagiellońskiego.

Trapszyc A., 2016, Słowo (nazwa) - kadr (widok) - pamięć (dziedzictwo). O istocie dialogu między materiq a duchem miasta [w:] M. Kwiecińska (red.), Niematerialne dziedzictwo miasta muzealizacja, ochrona, edukacja, Kraków: Muzeum Historyczne Miasta Krakowa.

Urbańczyk P., 2000, Political circumstances reflected in post-war archaeology , Public Archaeology”, t. 1: Maney Publishing.

Wołyńska M., 2018, Gdańskie dziedzictwo archeologiczne a wielkie inwestycje, trzy dekady zmagań [w:] J. Kolano, J. Kolasińska J., Rozpoznać przeszłość w teraźniejszości. Dziedzictwo w obliczu transformacji, Kraków: Akademickie Koło Studentów Ochrony Dóbr Kultury Uniwersytetu Jagiellońskiego.

Zalewska A., 2011, Archeologiczny palimpsest jako specyficzna postać interakcji teraźniejszości z ... [w:] A. Marciniak, D. Minta-Tworzowska, M. Pawleta (red.), Współczesne oblicza przeszłości, Poznań: Wydawnictwo Poznańskie.

Zalewska A., 2012, Miasto jako „obietnica zawsze nowych odkryć" w kontekście archeologii postrzeganej jako dyscyplina skazana na re-socjalizację i z perspektywy archeologii drugiego stopnia, „Analecta Archaeologica Ressoviensia", t. 7: Archaeology in a town, a town in archaeology, Rzeszów: Fundacja Rzeszowskiego Ośrodka Archeologicznego, Instytut Archeologii Uniwersytetu Rzeszowskiego.

Akty prawne:

Ustawa z dnia 21 listopada 1996 r. o muzeach, Dz.U. z 1997 r. Nr 5, poz. 24.

Ustawa z dnia 23 lipca 2003 r. o ochronie zabytków i opiece nad zabytkami, Dz.U. z 2003 r. Nr 162, poz. 1568. 
Źródła:

Hausbuch der Landauerschen...Bd. 1, 1511-1706, Hausbuch der Landauerschen Zwölfbrüderstiftung, Bd. 1, Stadtbibliothek Nürnberg.

Hausbuch der Mendelschen...Bd. 1, 1426-1549, Hausbuch der Mendelschen Zwölfbrüderstiftung, Bd. 1, Stadtbibliothek Nürnberg.

Hausbuch der Mendelschen...Bd. 2, 1550-1791, Hausbuch der Mendelschen Zwölfbrüderstiftung, Bd. 2, Stadtbibliothek Nürnberg.

Źródła internetowe:

Aertsen P., Taniec z jajkiem (1552), Rijksmuseum, Amsterdam, https://www.rijksmuseum.nl/nl/zoeken/objecten?q=aertsen\&p=6\&ps=12\&st=Objects\&ii=11\#/SK-A-3,71 [dostęp: 19.12.2017].

Doktowykłady, http://www.wbpg.org.pl/aktualnosc/doktowyk\%C5\%82ady [dostęp: 5.08.2018].

https://web.facebook.com/instytut.archeologii.umk/photos/a.1139457396184549.1073741838.52 4037054393256/1140030229460599/?type=3\&theater [dostęp: 27.12.2017].

https://encyklopedia.pwn.pl/szukaj/archeologia.html [dostęp: 7.08.2018].

Plakat z prelekcji „Tajemnice piwnic Senatu Wolnego Miasta Gdańska". Relacja z badań archeologicznych http://ibedeker.pl/wydarzenie/tajemnice-piwnic-senatu-wolnego-miasta-gdanska-w-filii-gdanskiej-wimbp/ [dostęp: 19.12.2017].

Plakat z prelekcji Targ Sienny w Gdańsku w świetle najnowszych badań archeologicznych (facebook MHMG) https://web.facebook.com/events/1747038035577346/ [dostęp: 27.12.2017]. 